\title{
Urban Sprawl and Growth Prediction for Lagos Using GlobeLand30 Data and Cellular Automata Model
}

\author{
Olalekan O. Onilude ${ }^{1}$ and Eric Vaz ${ }^{2, *}$
}

1 Environmental Applied Science and Management, Yeates School of Graduate Studies, Ryerson University, Toronto, ON M5B 2K3, Canada; oonilude@ryerson.ca

2 Department of Geography and Environmental Studies, Ryerson University, Toronto, ON M5B 2K3, Canada

* Correspondence: evaz@ryerson.ca

Citation: Onilude, O.O.; Vaz, E. Urban Sprawl and Growth Prediction for Lagos Using GlobeLand30 Data and Cellular Automata Model. Sci 2021, 3, 23. https://doi.org/10.3390/ sci3020023

Academic Editor: Claus Jacob

Received: 14 October 2020

Accepted: 15 October 2020

Published: 5 May 2021

Publisher's Note: MDPI stays neutral with regard to jurisdictional claims in published maps and institutional affiliations.

Copyright: (c) 2021 by the authors. Licensee MDPI, Basel, Switzerland. This article is an open access article distributed under the terms and conditions of the Creative Commons Attribution (CC BY) license (https:// creativecommons.org/licenses/by/ $4.0 /)$.

\begin{abstract}
Urban growth in various cities across the world, especially in developing countries, leads to land use change. Thus, predicting future urban growth in the most rapidly growing region of Nigeria becomes a significant endeavor. This study analyzes land use and land cover (LULC) change and predicts the future urban growth of the Lagos metropolitan region, using Cellular Automata (CA) model. To achieve this, the GlobeLand30 datasets from years 2000 and 2010 were used to obtain LULC maps, which were utilized for modeling and prediction. Change analysis and prediction for LULC scenario for 2030 were performed using LCM and CA Markov chain modeling. The results show a substantial growth of artificial surfaces, which will cause further reductions in cultivated land, grassland, shrubland, wetland, and waterbodies. There was no appreciable impact of change for bare land, as its initial extent of cover later disappeared completely. Additionally, artificial surfaces/urban growth in Lagos expanded to the neighboring towns and localities in Ogun State during the study period, and it is expected that such growth will be higher in 2030. Lastly, the study findings will be beneficial to urban planners and land use managers in making key decisions regarding urban growth and improved land use management in Nigeria.
\end{abstract}

Keywords: urban sprawl; GlobeLand30; LULC change; remote sensing; cellular automata; Markov chain; growth prediction; Lagos

\section{Introduction}

Globally, rapid population growth is intense in cities, and is a major factor for land use change [1]. Land use and land cover (LULC) change is a serious global environmental problem because the changing aspects of LULC are greatly affected by climate [2,3]. Urbanization is the movement of rural residents to urban regions with subsequent population increases in urban regions [4]. Additionally, urbanization is the result of socio-economic and political developments that lead to an expansion of big cities and changes in land use [5,6]. Additionally, urban sprawl is simply a segment of urban growth [7]. Urban sprawl is a global occurrence, and it attracts the attention of urban planners because of its nexus with the environmental efficiency of cities [8]. Urban sprawl is defined as "a pattern of land-use in an urban area that exhibits low levels of some combination of eight district dimensions: density, continuity, concentration, clustering, centrality, nuclearity, mixed used and proximity" [9]. The Merriam-Webster dictionary define urban sprawl as "the spreading of urban developments on undeveloped land near a city"; and it is widely known as "an undesirable form of development, due to its economic, social and environmental disadvantages" [10]. Thus, urban sprawl has a complex effect on the "structure and function of ecosystems in urban areas" [11].

Urbanization creates opportunities, and it also causes problems for human life. Some land use planners think that urban sprawl enhances the quality of life and promotes economic growth [12]. However, the growing human activity in urban areas contributes to changes in land use and subsequent adverse effects on such affected urban areas $[13,14]$. 
Similarly, rapid urban growth has caused some environmental problems, such as the loss of agricultural land, land degradation, water shortages, and pollution [1]. In developing countries, unrestrained and rapid growth leads to formation of slums, inequity, and the absence of appropriate infrastructure in terms of roads, shelter, water, and hygiene [15,16]. Likewise, the quick change in built-up land cover or urban sprawl in the Lagos metropolis produces the shortage of infrastructure (such as roads, suitable drainage constructions, waste collection and disposal infrastructure) that cannot cope with the rate of development [17]. Monitoring landscape pattern changes gives an implied method for describing the environmental effects of urbanization $[14,18,19]$.

Presently, $55 \%$ of the world's population lives in cities, and this percentage is estimated to increase to $68 \%$ in 2050 [20]. Similarly, the population of city residents worldwide is expected to increase by 2.5 billion by 2050 . The anticipated population increase will occur in developing nations, with an almost $90 \%$ increase in Asia and Africa [20]. Nigeria has a population of over 200 million [21], which makes it the most populous country in Africa [22]. It is predicted that by 2050, Nigeria will be the third most populated country in the world, with an estimated population of over 398 million [20]. Urbanization in Nigeria began over one hundred years ago according to Mabogunje [23]. Prior to Nigeria's independence in 1960, the urban population growth was extremely low [24]; after 1960, only the cities of Lagos and Ibadan had populations higher than half a million people each, while almost a hundred thousand people resided in the remaining twenty-four cities across the country [24,25]. However, an incomparably high level of urbanization happened between 1970 and 1995, supposedly the fastest global urbanization growth rate at that period [26]. This population increase was ascribed to the 1970s and 1980s crude oil boom with resultant development projects across the country, as well as the influx of people to the cities [24]. Figure 1 shows the total population of Nigeria by variant.

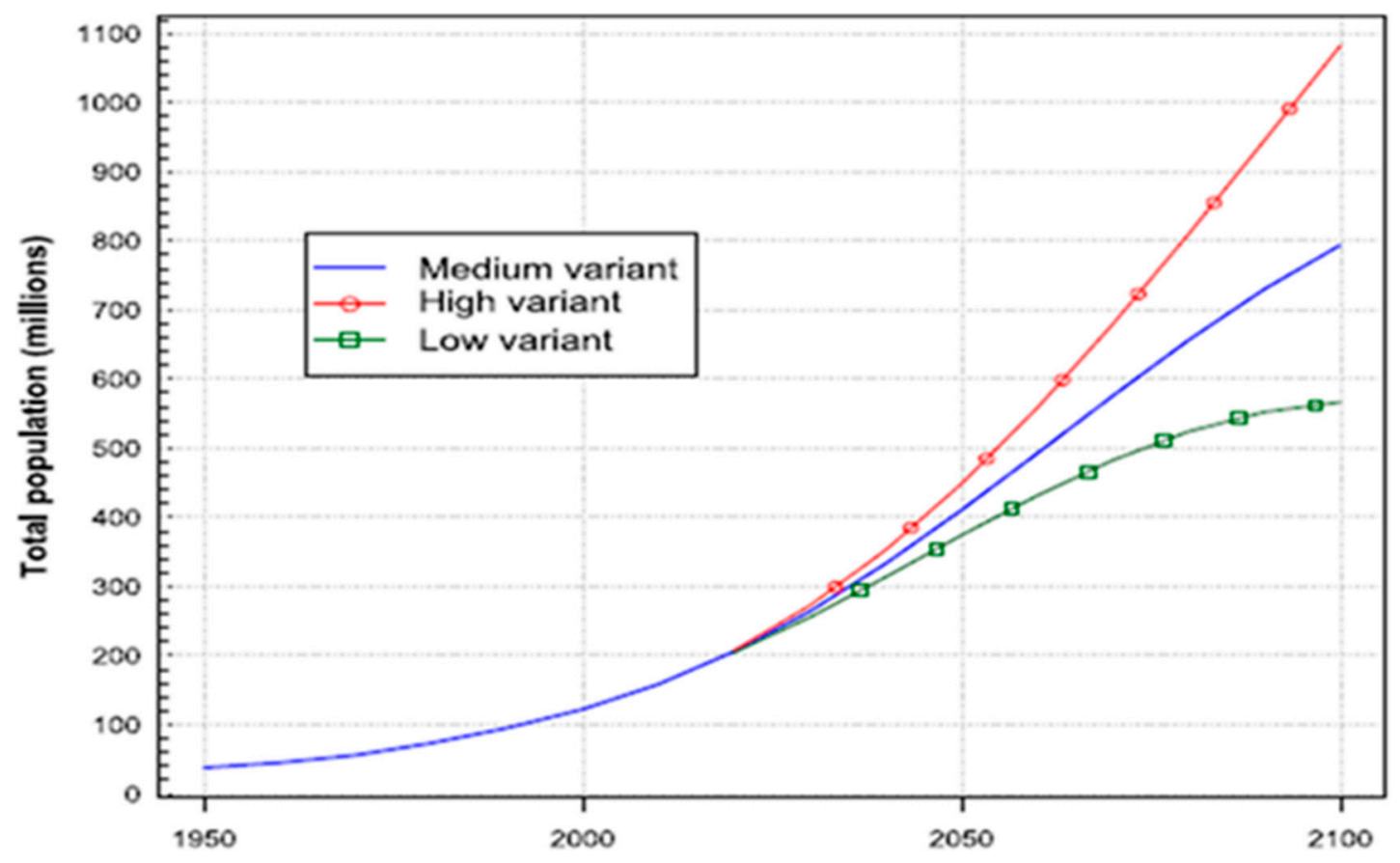

Figure 1. Total population of Nigeria by variant. Source: United Nations, Department of Economic and Social Affairs, Population Division [27].

It is worth mentioning that land use activity from the perspective of urban development is important, as it ensures the variety of economic growth without endangering scarce natural resources [28]; also, it equates livable and social equity within the changing aspects of current urban growth [29]. Hence, the evaluation of land use change is a focus of continuing economic theory of creating contemporary and habitable cities [30] in developing 
countries (e.g., Nigeria) that encounter problems in situating themselves as prospective urban centers [31].

Various types of spatial techniques and models are applicable for analysis in urban sprawl and land use change research. Globally, Geographic Information Systems (GIS) integrated with Remote Sensing (RS) are potent and cost-effective tools that have been extensively used for identifying and analyzing the spatiotemporal dynamics of processes of LULC change and urban growth on general scale [32-34]. Some growth models include Markov chains [35], cellular automata (CA) [30,36-38], spatial logistic regression [39], artificial neural networks (ANN) [40,41], and multicriteria evaluation [42]. Among the above-mentioned models, CA have been extensively utilized to assess land change and urban expansion globally [43,44]. Notably, GIS-based CA models are efficient in simulating urban growth processes and estimating spatial patterns of urban growth [45-47].

However, the integration of CA with other techniques might improve the standardization of CA-based urban models. Thus, the combination of CA and Markov Chains (CA Markov) is a hybrid model that merges the theories and benefits of CA and Markov Chains [48-50]. In comparison with other models, this hybrid is the most generic and effective in forecasting future LULC changes with various scenarios [51]. Thus, the future prediction of LULC change is attained through a blend of LULC models with RS and GIS [52].

Notwithstanding a significant rise in the number of studies completed on the spatial perception of urban growth and LULC change over the years in Lagos metropolis (e.g., [17, 53-59]), none of these studies used GlobeLand30 product. This global dataset is useful for Nigeria and provides the opportunity to make comparisons with data from developed countries such as Canada. Therefore, the aim of this study is to analyze LULC change from 2000 to 2010, and to predict future urban growth using the GlobeLand30 dataset, GIS, and the CA model. Additionally, modeling the urban land use changes of a region such as Lagos requires the utilization of strong methods that can model the growth, complex nature, and urban changing aspects [60]. Thus, analyzing LULC and making predictions of future urban growth will enhance the decision-making process concerning the land use and sustainable environment in Lagos and Nigeria at large.

\section{Materials}

\subsection{Study Area}

Lagos is the area of study. It was the administrative capital of Nigeria until 1991, when the headquarters was relocated to the federal capital territory (FCT) in Abuja [61]. Metropolitan Lagos is typified by a quite flat terrain and coastal depositional features: Wetlands, beaches, and estuaries [55]. With an estimated population of over 14 million [27], Lagos is the largest city in Nigeria. Lagos State covers an area of approximately 3671 square kilometers (1,443.98 square miles) [62]. It is in the southwestern part of the country and situated on longitude $2^{\circ} 42^{\prime}-4^{\circ} 20^{\prime}$ East and latitude $6^{\circ} 22^{\prime}-6^{\circ} 42^{\prime}$ North. Additionally, it is bordered by the Republic of Benin in the West, with Ogun State in the North and East, as well as the Atlantic Ocean in the South [63]. The high-density metropolitan region of Lagos where this study was conducted comprises sixteen Local Government Areas (LGAs) identified with numbers: (1) Agege; (2) Ifako-Ijaye; (3) Alimosho; (4) Ikeja; (5) Shomolu; (6) Kosofe; (9) Oshodi-Isolo; (10) Mushin; (12) Ojo; (13) Amuwo Odofin; (14) Ajeromi Ifelodun; (15) Surulere; (16) Lagos Mainland; (17) Lagos Island; (18) Apapa; and (19) Eti Osa. The four rural LGAs: (7) Ikorodu; (8) Epe; (11) Badagry; and (20) Ibeju Lekki, were not studied (see Figure 2). 

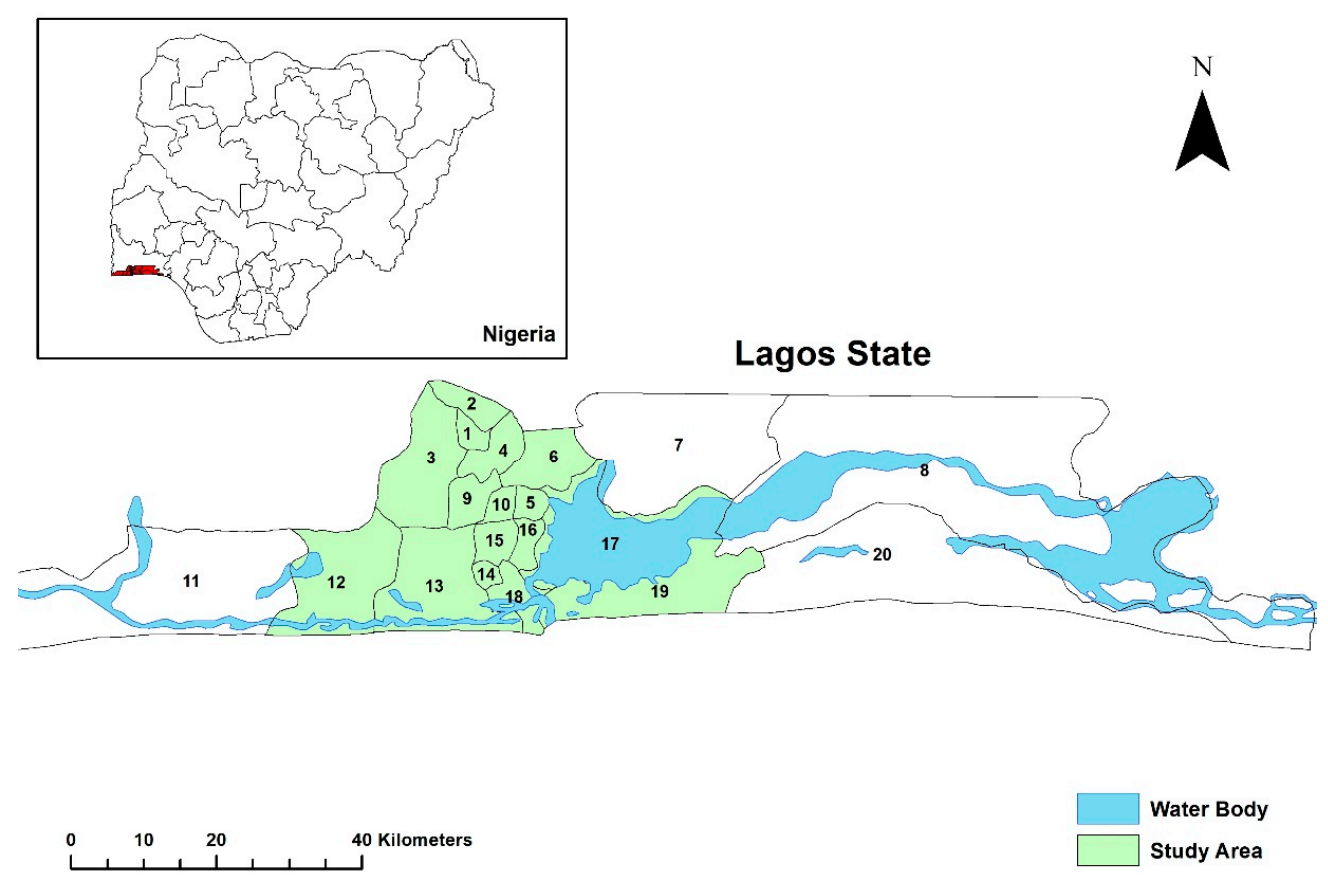

Figure 2. Map of Lagos State showing the area of study (metropolitan region).

The expansion of metropolitan Lagos has been occurring since the colonial era [64], and it was projected that by 2025, Lagos will attain a population of 18.8 million and surpass numerous cities worldwide [65]. The population of Lagos and its average annual rates of change between 1970 and 2025 are presented in Table 1.

Table 1. Population of Lagos and its average annual rates of change for 1970-2025.

\begin{tabular}{ccccccc}
\hline & \multicolumn{3}{c}{ Population (Millions) } & \multicolumn{4}{c}{ Average Annual Rate of Change (Percentage) } \\
\hline 1970 & 1990 & 2011 & 2025 & $1970-1990$ & $1990-2011$ & $2011-2025$ \\
\hline 1.4. & 1.8 & 11.2 & 18.9 & 6.08 & 4.08 & 3.71 \\
\hline
\end{tabular}

Source: United Nations [65].

Lagos metamorphosed from a less important agricultural community (i.e., originally a settlement of farmers and fishermen) to its current megacity status [66]. It is a commercial center with a seaport, and it serves as an international hub for trade [67]. Thus, Nigeria's economy is dependent on Lagos, as it has 85 percent of the industrial sector, 65 percent of the financial sector, and 75 percent of the workforce [68]. Accordingly, people move to Lagos because of the job prospects and enthusiasm to create business and wealth [69]. Additionally, the British decision to keep Lagos as Nigeria's Capital City after the country's amalgamation in 1914 significantly determined the pace, pattern, and nature of land use development in Metropolitan Lagos [70].

In 2012, the Citigroup and Urban Land Institute ranked Lagos as one of the most innovative cities in Africa. This ranking was based on population, sustainability, quick economic advancement, and potential for investors [71]. In the olden days, land use management in Lagos had been solely under the Traditional Law of the Yoruba Custom. This type of land administration is a process by which land is registered at the request of the land buyer [72]. The creation of Lagos State in 1976 led to the establishment of Land Registry [72], and afterwards, the Lands Bureau in 1999 to implement the State government land administration policy [66]. The land registry keeps and stores the records of all land transactions and other instruments affecting lands in the State. Proper record keeping ensures effective management of land, and it also supports equitable and sustainable access of land in Lagos [73]. 
The urban growth of the Lagos metropolitan region has broadened beyond the land of Lagos State to bordering towns and localities of Ogun State. Specifically, this study encompasses a total area of $85 \mathrm{~km} \times 60 \mathrm{~km}$, which is an integration of the Lagos metropolitan region (i.e., 16 urban LGAs of Lagos State) with a portion of the bordering Ogun State.

\subsection{Research Data}

In this study, the remotely sensed data and ancillary were used. A description of the collected data is illustrated in Table 2.

Table 2. Description of the collected remotely sensed and geospatial data.

\begin{tabular}{cccc}
\hline Data Type & Dataset & Resolution & Source \\
\hline Land use & GlobeLand30 & $30 \mathrm{~m}$ multispectral & National Geomatics Centre of China \\
\hline Physical objects & OpenStreetMap & www.openstreetmap.org accessed \\
on 28 April 2020
\end{tabular}

The GlobeLand30 is a product of the National Geomatics Centre of China; it covers the time from 2000 to 2010 and has 30m-high resolution imagery [74]. GlobeLand30 are produced through the collection of over 10,000 Landsat satellite images and through the implementation of a "pixel-object-knowledge" method [75]. For this study, the GlobeLand30 for years 2000 and 2010 were obtained from http:/ / www.globallandcover.com accessed on 28 April 2020. Additionally, GlobeLand30 classification consists of ten land cover types: Cultivated land, forest, grassland, shrubland, wetland, water bodies, tundra, artificial surfaces, bare land, and permanent snow and ice [76]; however, eight of these land covers types are relevant to Nigeria, as itemized in Table 3. An accuracy assessment was performed by Arowolo and Deng [77] on GlobeLand30 applying Google Earth images in a research on LULC change in Nigeria. This dataset presented an overall accuracy of greater than $73 \%$ and $75 \%$ in 2000 and 2010, respectively, which indicates its appropriateness for this research.

Table 3. Land cover classification of GlobeLand30 utilized for the study [76].

\begin{tabular}{|c|c|c|}
\hline Land Cover Code & $\begin{array}{l}\text { Land Cover } \\
\text { Type }\end{array}$ & Attributes of Land Type \\
\hline 10 & Cultivated land & $\begin{array}{l}\text { Lands used for agriculture, horticulture, and gardens, including paddy fields, } \\
\text { irrigated and dry farmland, vegetation, and fruit gardens, etc. }\end{array}$ \\
\hline 20 & Forest & $\begin{array}{l}\text { Lands covered with trees, with vegetation cover over } 30 \% \text {, including deciduous } \\
\text { and coniferous forests, and sparse woodland with cover } 10-30 \% \text {, etc. }\end{array}$ \\
\hline 30 & Grassland & Lands covered by natural grass with a cover over $10 \%$. \\
\hline 40 & Shrubland & $\begin{array}{l}\text { Lands covered with shrubs with a cover over } 30 \% \text { including deciduous and } \\
\text { evergreen shrubs and desert steppe with a cover over } 10 \% \text {, etc. }\end{array}$ \\
\hline 50 & Wetland & $\begin{array}{l}\text { Lands covered with wetland plants and water bodies including inland marsh, } \\
\text { lake marsh, sea marsh, river floodplain wetland, forest/shrub wetland, peat } \\
\text { bogs, mangrove, and salt marsh, etc. }\end{array}$ \\
\hline 60 & Water bodies & Water bodies in the land area, including river, lake, reservoir, fish pond, etc. \\
\hline 80 & Artificial surfaces & $\begin{array}{l}\text { Lands altered by human activities, including all kinds of habitations, industrial } \\
\text { and mining area, transportation facilities, and interior urban green zones and } \\
\text { water bodies, etc. }\end{array}$ \\
\hline 90 & Bare land & $\begin{array}{l}\text { Lands with vegetation cover lower than } 10 \% \text { including desert, sandy fields, } \\
\text { Gobi, bare rocks, saline and alkaline lands, etc. }\end{array}$ \\
\hline
\end{tabular}


Table 2 also contains OpenStreetMap (OSM) and digital elevation model (DEM) data type. OSM is the "Wikipedia of Maps", and freely available to download for any region globally. It is a road network dataset that is always updated [78]. The shapefiles of the roads in the Lagos metropolitan region were extracted from the 2017 OSM. Additionally, the Shuttle Radar Topography Mission (SRTM) 1 (2000) DEM of $30 \mathrm{~m}$ spatial resolution data was downloaded from Earth Explorer website and utilized to generate the slope and elevation. Thus, SRTM 1 DEM and OSM are ancillary data required to improve the quality [79] and complement the GlobeLand30 data.

\section{Methods}

Figure 3 shows the study flowchart and procedures that were carried out. These include the GlobeLand30 data 2000 and 2010, the formation of LULC maps, choice of variables, change analysis, transition potential modeling and prediction employing LCM and CA Markov chain techniques.

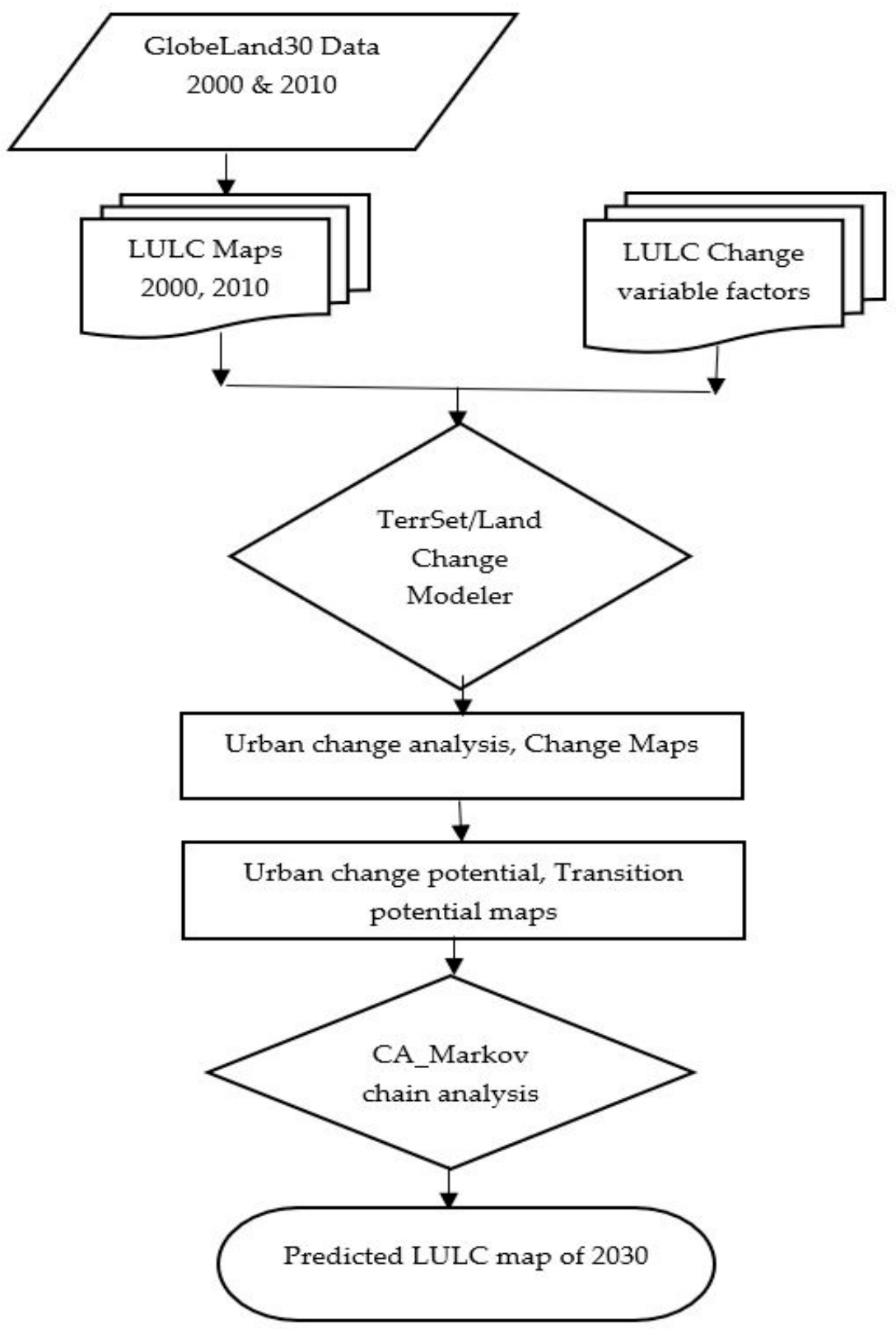

Figure 3. Flowchart of methods. 


\subsection{LULC Classified Maps}

Figure 4 illustrates the 2000 and 2010 classified maps of the study area that were created using the Esri ArcGIS 10.6 software to perform the analysis of the GlobeLand30 data. The reference system applied was the Universal Transverse Mercator (UTM) projection within zone 31 North with World Geodetic System (WGS) 1984 at $30 \mathrm{~m}$ spatial resolution.

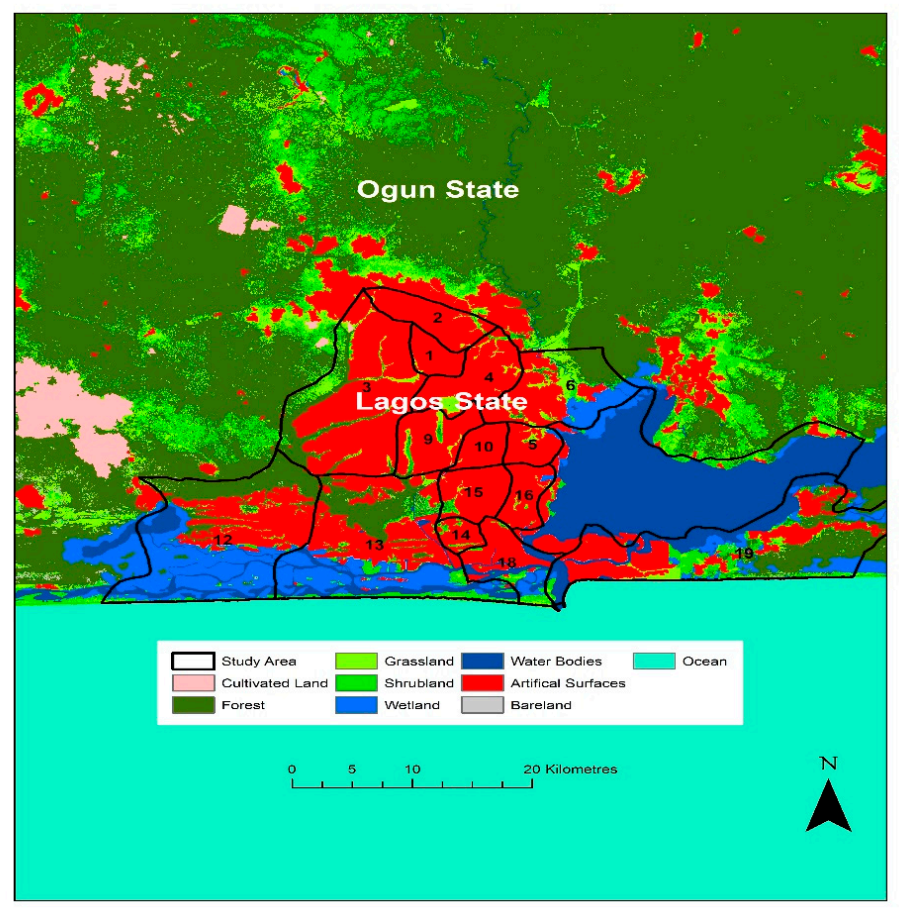

(a)

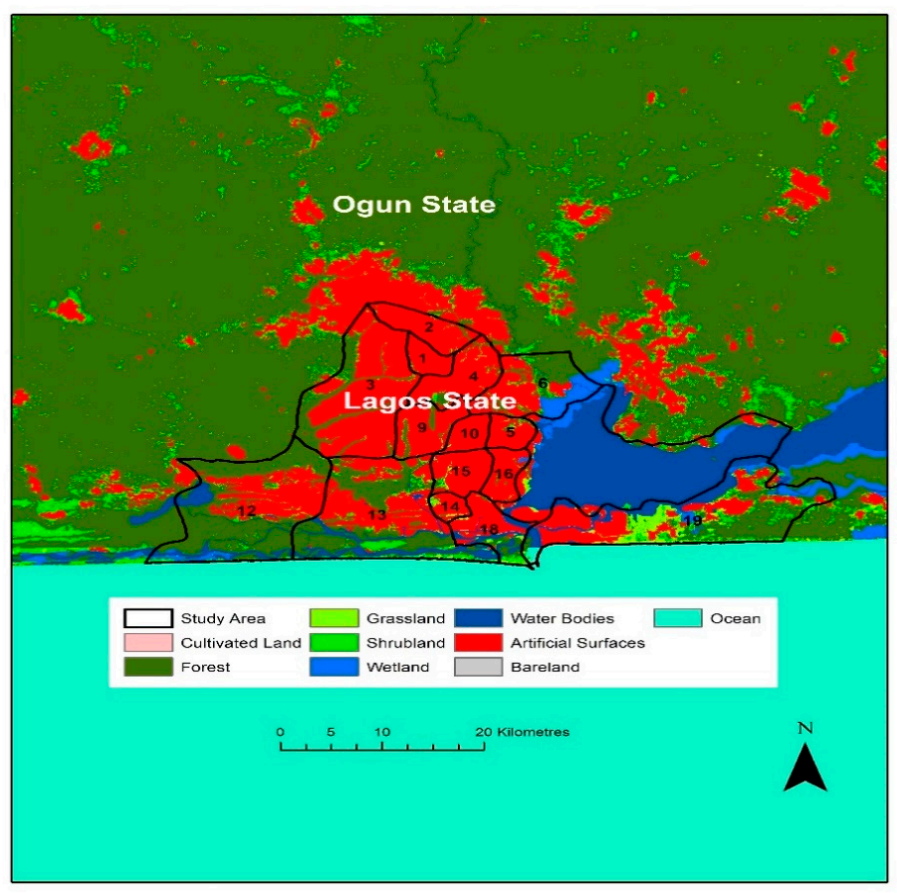

(b)

Figure 4. (a) Classified map of the year 2000. (b) Classified map of the year 2010. 


\subsection{Change Detection Analysis}

This analysis was conducted using LCM within TerrSet software system. The LCM is a decision support software which is suitable for assessing and predicting future land cover change with implications for sustainable development [80]. Accordingly, the change analysis depends on the land use changes between period 1 and period 2 [81]. Thus, the classified GlobeLand30 maps of period 1 (2000) and period 2 (2010) for Lagos metropolitan region were imported into the Change Analysis tab within LCM for analysis. Next, the gains, losses, and net changes in LULC for 2000 and 2010 were produced.

\subsection{Selection of LULC Transitions}

Major and minor transitions occur between LULC maps of two-time intervals. However, major transitions were chosen for this research, and they were grouped into the transition submodels; then, each transition was modeled applying the enhanced multilayer perceptron (MLP) neural network [82]. This study used a $20 \mathrm{~km}^{2}$ threshold, which represents less than 0.5 percent of the total area of study, and thus, reduces the number of transitions from 49 to the following nine major transitions: Grassland to forest, shrubland to forest, wetland to forest, artificial surfaces to forest, forest to shrubland, grassland to shrubland, forest to artificial surfaces, grassland to artificial surfaces, and shrubland to artificial surfaces.

\subsection{Selection of Variables}

There is no general recommendation for selecting the driving forces for LULC changes. However, selection was made especially for each study area based on the uniqueness of each region concerning the driving factors that affect its urban growth [83]. Thus, the appropriateness of different factors could differ from one study to another $[84,85]$. Constraints are measures that can restrict the development of artificial surfaces. A constraint is specified like the Boolean map, and it signifies that a value of 0 (not suitable) is apportioned to the areas (i.e., LULC types) that are excluded, while areas included are apportioned a value of 1 (suitable) [86]. This study conceived water bodies and existing artificial surfaces as constraints. Thus, the factors and constraints were standardized in the TerrSet software. In this analysis, a 0-255 scale was used to standardize the factors (see Figure 5 for standardized factors/variables).

In the past years, urban driving factors have been applied in CA modeling to predict possible urban growth [83]. These driving factors include physical, human disturbance, economic, and institutional, all of which are significant to urban LULC change. Topography is a type of physical factor; it affects the size and spatial spreading of a city by restricting the provision of adequate land and water [87]. Generally, slope and elevation constitute the most significant topographic factors [88,89]; human disturbance/proximity factors, e.g., distance to road $[87,90,91]$, and distance to water bodies [88,92] are all key determining factors for urban growth. Thus, roads play an important part in urbanization because they enable citizens to have access to various services on a daily basis. Socio-economic factors, i.e., population density and the gross domestic product, were excluded in the submodel and computation units in the analysis of this study. Institutional factors such as urban planning and land development regulations are also important determinants of urban growth dynamics $[93,94]$.

In this study, a total of five variables were chosen and weighed for their impacts on urban growth. These included static variables such as elevation, slope, and distance from water bodies, while dynamic variables comprised distance from major roads and distance from existing artificial surfaces. Static variables are unchanging over time, whereas dynamic variables can change and are recomputed over time during a prediction [82]. In summary, the major LULC transitions and driving factors represent the two model variables that were included for the submodeling. Figure 5 depicts the standardized variables for this study. 


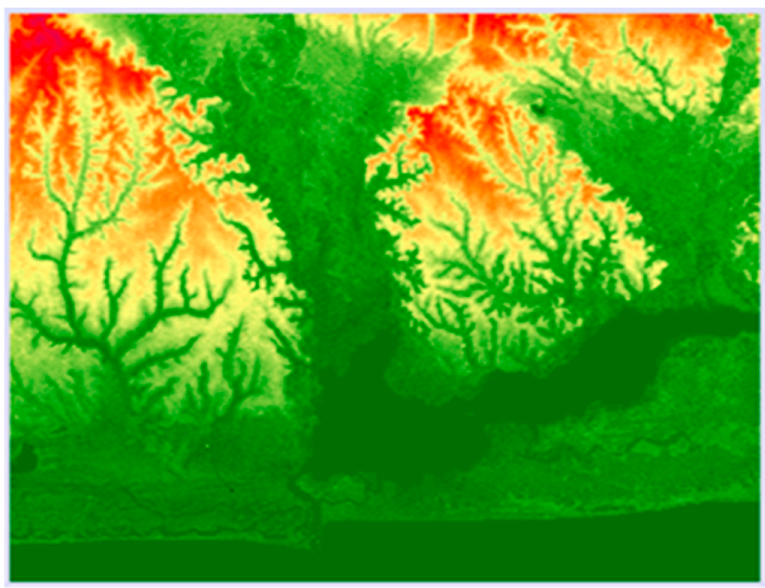

(a) Elevation

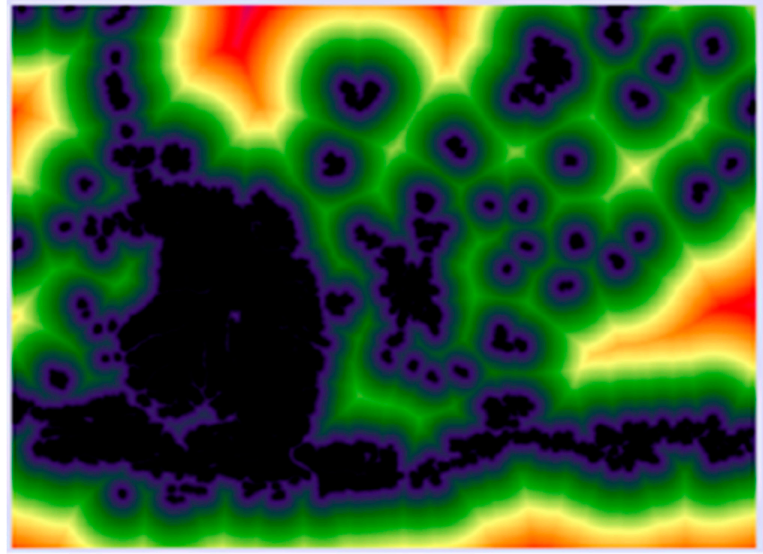

(c) Distance from artificial surfaces

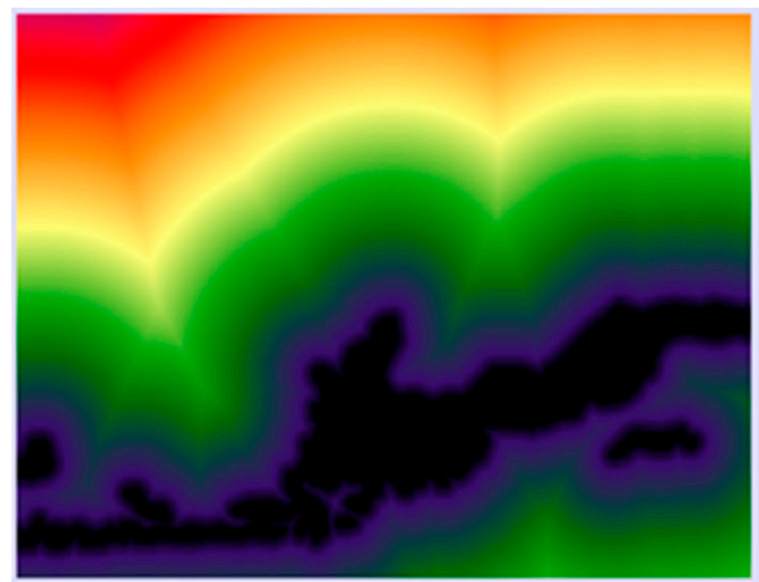

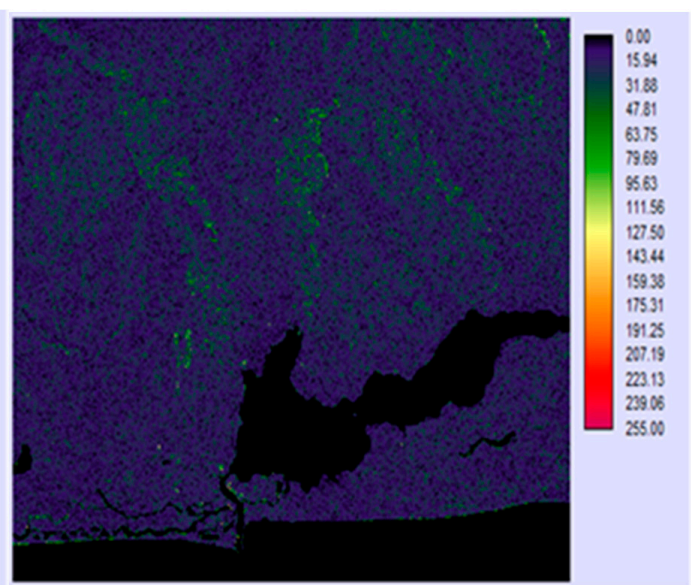

(b) Slope

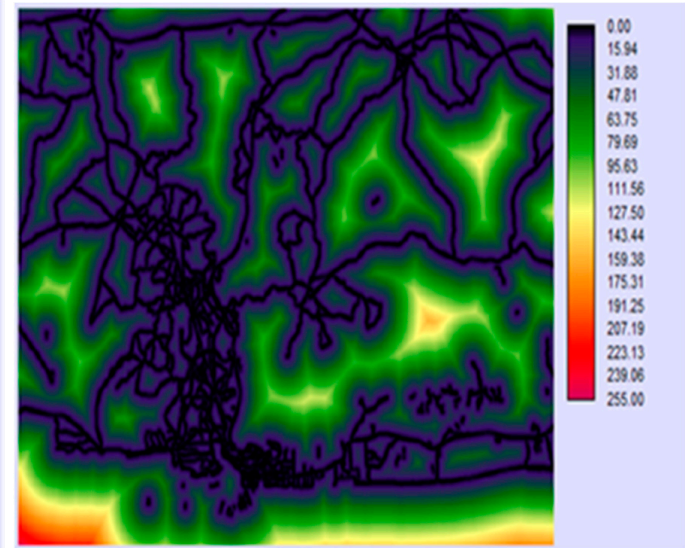

(d) Distance from major roads

(e) Distance from water bodies

Figure 5. Standardized factors (variables) used in the study: (a) Elevation, (b) slope, (c) distance from artificial surfaces, (d) distance from major roads, and (e) distance from water bodies.

\subsection{Transition Potential Modeling}

This phase is necessary to identify the consequential LULC transitions, and to create transition potential maps with satisfactory degrees of accuracy to run the transition models. The transition potential maps were obtained based on LULC transitions, together with static and dynamic variables using an MLP neural network, a component of LCM. The MLP 
is a frequently used type of artificial neural network (ANN) that is built on a supervised "backpropagation" (BP) training algorithm [95,96].

The MLP neural network supervised BP algorithm is used to adjust the parameter or weight and bias of the model to minimize error and improve accuracy [96]. Accordingly, an accuracy rate of around $80 \%$ is acceptable [81]. The results of the current research of the MLP after 10,000 iterations produced an accuracy of $82.85 \%$ for LULC changes in Lagos metropolitan region between 2000 and 2010. Thus, the transition potential maps that were produced from this process were used to predict future LULC changes.

\subsection{LULC Change Prediction}

This study utilized the CA Markov chain built in LCM module within TerrSet software, version 18.3 to predict future patterns of LULC change using GlobeLand30 maps of years 2000 and 2010 in Lagos metropolitan region.

A CA model comprises set of similar elements or cells that are non-linear; it has the ability to simulate the spatiotemporal attributes of complex systems $[97,98]$. CA postulate that the present state of land use and changes in the neighboring cells describe the land use change for any location (cell) [99]. Additionally, CA can be stated in simply numerical notations [100], and they can calculate functions and solve algorithmic problems [101]. Markov chains are largely utilized for modeling LULC; they describe the land use change between two-time intervals considering the trend of historical LULC [102,103]. The result from this model depends on the probability of transition [104], and the transition probability matrix of LULC change from first time to second time will help to predict the time for the future [103].

During this study, the MLP neural network helped to ascertain the weights of the transitions to be incorporated in probability matrices of Markov chain to predict the future LULC change. Thus, the matrix derived from the Markov chain analysis consists of the anticipated quantity of changes for each weighed transition until the predicted closing dates. Accordingly, the transition probability matrix was quantified for LULC changes between 2000 and 2010. Finally, the prediction for 2030 was performed utilizing CA Markov chain, and probable LULC changes were ascertained.

\section{Results and Discussions}

\subsection{LULC Distribution}

Table 4 shows the distribution of LULC classes between 2000 and 2010. The results presented substantial changes for forest and artificial surfaces, and forest showed the greatest changes among all the land cover types. It was observed that in 2000, forest covered an area of 2,636.10 $\mathrm{km}^{2}(58.23 \%)$, which increased to $2954.44 \mathrm{~km}^{2}(65.32 \%)$ in 2010 . Thus, forests grew by $7.09 \%$ during this period. The increased forest growth in Lagos metropolitan area can be ascribed to developed parks and the planting of trees undertaken by the Ministry of the Environment starting in 2008. Afforestation was aimed to mitigate the potential adverse effects of global warming and subsequently promote an eco-friendly and healthier environment [105]. Additionally, since the inception of the tree planting program, government records show that a total of six million, two hundred and three thousand, five hundred and fifty-three $(6,203,553)$ trees have been planted in the entire Lagos State [105].

Additionally, during the period of study, artificial surfaces covered an area of $723.72 \mathrm{~km}^{2}$ $(15.99 \%)$ in 2000 , and they increased to $796.16 \mathrm{~km}^{2}(17.60 \%)$ in 2010 . Artificial surfaces therefore increased by $1.61 \%$ during this period. This increase can be attributed to increasing demand of land from a growing population and the development of housing, transit facilities, industrial buildings, and urban greenspaces near the study area. Thus, both the forest and artificial surfaces exhibited substantial changes between 2000 and 2010 in metropolitan Lagos. 
Table 4. Area statistics and number of changes in land use and land cover (LULC) during 2000 to 2010.

\begin{tabular}{ccccc}
\hline Year & \multicolumn{2}{c}{$\mathbf{2 0 0 0}$} & \multicolumn{2}{c}{$\mathbf{2 0 1 0}$} \\
\hline LULC Class & Area $\mathbf{( k m}^{\mathbf{2}} \mathbf{)}$ & Area $\mathbf{( \% )}$ & Area $\mathbf{( k m}^{\mathbf{2}} \mathbf{)}$ & Area (\%) \\
\hline Cultivated land & 24.42 & 0.54 & 1.33 & 0.03 \\
Forest & 2636.10 & 58.23 & 2954.44 & 65.32 \\
Grassland & 236.61 & 5.23 & 41.52 & 0.92 \\
Shrubland & 234.25 & 5.17 & 185.05 & 4.09 \\
Wetland & 228.99 & 5.06 & 121.81 & 2.69 \\
Water bodies & 438.97 & 9.70 & 423.06 & 9.35 \\
Artificial surfaces & 723.72 & 15.99 & 796.16 & 17.60 \\
Bare land & 4.28 & 0.09 & - & - \\
Total & 4527.34 & 100.00 & 4523.37 & 100.00 \\
\hline
\end{tabular}

Moreover, cultivated land covered an area of $24.42 \mathrm{~km}^{2}(0.54 \%)$ in 2000, which decreased to $1.33 \mathrm{~km}^{2}(0.03 \%)$ in 2010 , displaying a loss of $0.51 \%$ during this period. Due to the decrease of cultivated land, artificial surfaces showed a small increment. This could be caused by rapid population growth linked with the demand for land and urban supplies. This result concurs with the research findings asserting that land conversion occurs at the boundary of cities, and the pressures from urban sprawl and industrial development often result in loss of main agricultural lands [106].

Similarly, grassland with a covered area of $236.61 \mathrm{~km}^{2}(5.23 \%)$ in 2000 presented large reduction, i.e., to $41.52 \mathrm{~km}^{2}(0.92 \%)$ in 2010 , showing a loss of $4.31 \%$. Additionally, shrubland, wetland, and water bodies showed reductions in the quantities of area that they covered. The findings showed a $1.08 \%$ decrease for shrubland, a $2.37 \%$ decline for wetland, and a $0.35 \%$ reduction for water bodies between 2000 and 2010 . The decrease in water bodies concurs with the report of Obiefuna et al. [17], i.e., that the reduction in water bodies could have occurred because of land filling of Lagos lagoon for residential development [17]. Furthermore, bare land exhibited the lowest proportion of land cover among all other land cover types that showed percentage reductions. Bare land covered a small area, $4.28 \mathrm{~km}^{2}(0.09 \%)$, in 2000, but no area was covered (i.e., zero land cover) in 2010, implying that the smallest land cover for bare land in 2000 disappeared completely in 2010 in the Lagos metropolitan region.

\subsection{LULC Change Analysis Using LCM}

Table 5 depicts the gains, losses, and net changes in LULC between 2000 to 2010 in the study area.

Table 5. Gains, losses, and net changes $\left(\mathrm{km}^{2}\right)$ in LULC from 2000 to 2010.

\begin{tabular}{cccc}
\hline Year & & 2000-2010 Period & \\
\hline LULC Class & Losses & Gains & Net Changes \\
\hline Cultivated land & -24.21 & 1.12 & -23.09 \\
Forest & -137.11 & 455.45 & 318.34 \\
Grassland & -221.98 & 27.62 & -194.36 \\
Shrubland & -194.80 & 146.25 & -48.55 \\
Wetland & -134.56 & 27.43 & -107.14 \\
Water bodies & -25.51 & 12.14 & -13.36 \\
Artificial surfaces & -53.08 & 125.52 & 72.44 \\
Bare land & -4.28 & 0.00 & -4.28 \\
\hline
\end{tabular}

The results clearly show that between 2000 and 2010, forest experienced significant gains and losses, with $455.45 \mathrm{~km}^{2}$ gains and $137.11 \mathrm{~km}^{2}$ losses, as well as a substantial net gain of $318.34 \mathrm{~km}^{2}$, which was the highest among the land cover types. Additionally, artificial surfaces increased with a gain of $125.52 \mathrm{~km}^{2}$, a loss of $53.08 \mathrm{~km}^{2}$, and a net gain 
of $72.44 \mathrm{~km}^{2}$. Moreover, cultivated land, grassland, shrubland, wetland, water bodies, and bare land all presented negative net changes. Grassland showed the greatest negative net change of $194.36 \mathrm{~km}^{2}$; it lost about $221.98 \mathrm{~km}^{2}$ and gained $27.62 \mathrm{~km}^{2}$; shrubland lost $194.80 \mathrm{~km}^{2}$, gained $146.25 \mathrm{~km}^{2}$, and showed a net loss of $48.55 \mathrm{~km}^{2}$; wetland lost $134.56 \mathrm{~km}^{2}$; it gained $27.43 \mathrm{~km}^{2}$, and displayed large net loss of $107.14 \mathrm{~km}^{2}$. Water bodies showed $25.51 \mathrm{~km}^{2}$ loss, $12.14 \mathrm{~km}^{2}$ gain, and a net loss of $13.36 \mathrm{~km}^{2}$. In addition, cultivated land lost $24.21 \mathrm{~km}^{2}$, gained $1.12 \mathrm{~km}^{2}$, and demonstrated a net loss of $23.09 \mathrm{~km}^{2}$.

Figure 6 shows the gains and losses in the study area from 2000 to 2010.

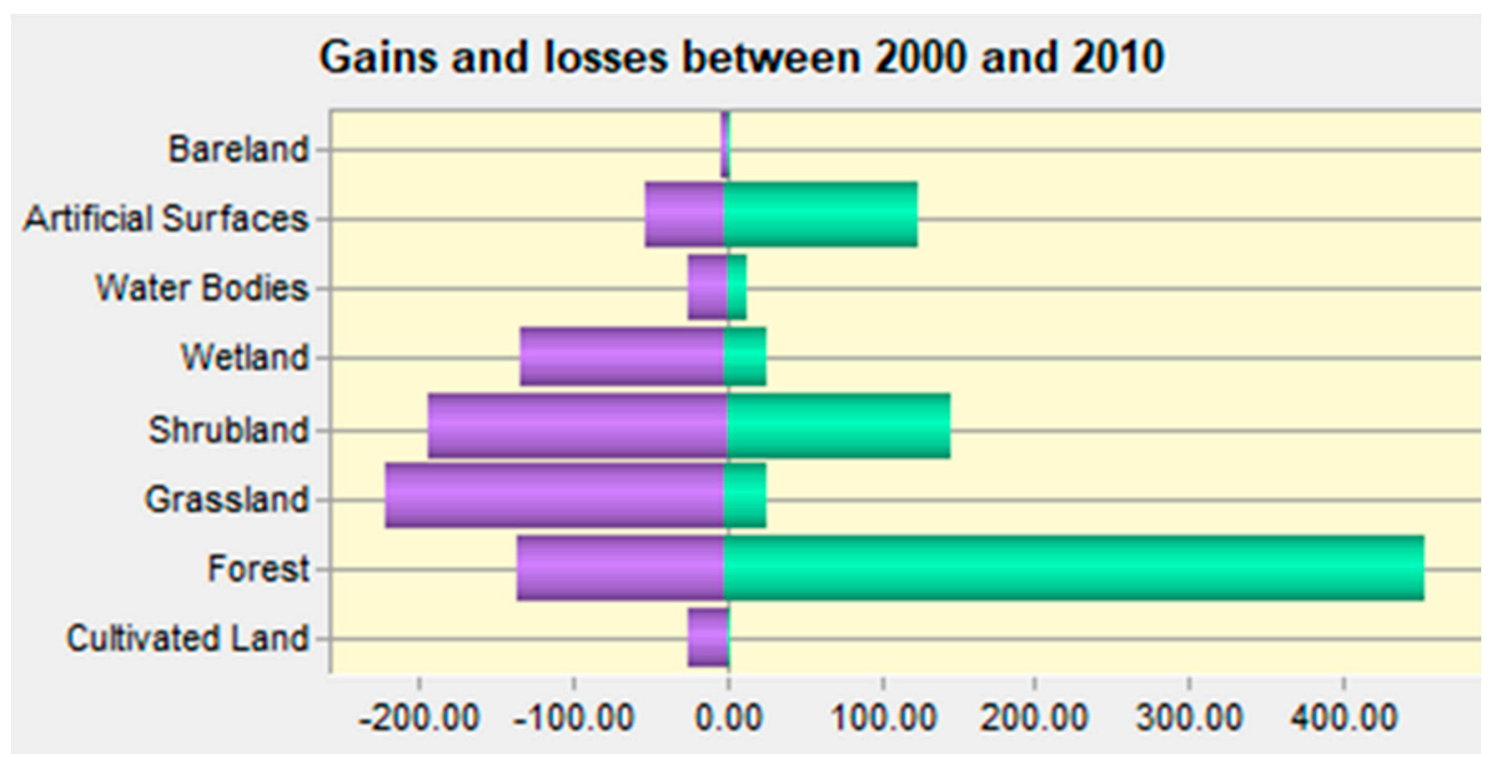

Figure 6. Gains and losses in LULC $\left(\mathrm{km}^{2}\right)$ between 2000 and 2010.

Furthermore, the study showed that bare land lost $4.28 \mathrm{~km}^{2}$ with zero gains and net loss of $4.28 \mathrm{~km}^{2}$.

In summary, it is evident from the findings within the period of the study that: (1) The extents of forest and artificial surfaces in terms of gains and net changes were substantial; (2) there was substantial loss of vegetation (i.e., grassland and shrubland) and shrinkage of wetland; and (3) bare land with zero gains seemed not to show any appreciable impact of change in comparison with other land cover types. Findings concerning artificial surfaces and bare land concur with Arsanjani [107], who proposed that bare land can show a negative land change, whereas development of artificial surfaces, e.g., greenspaces, might display a positive change based on local conditions. This implies that Arsanjani's report is applicable to the situation in the Lagos metropolitan region.

Figure 7 illustrates net changes in LULC from 2000 to 2010.

Regarding LULC distribution, the results show that the development of artificial surfaces occurred within and outside the frontier of Lagos State, and extended to bordering Ogun State (see Figure 4a,b). This report corroborates a research outcome which stated that approximately $50 \%$ of the growth of artificial surfaces in Lagos metropolitan region happened outside the administrative frontier of Lagos and extended to nearby areas in Ogun State [108]. Similarly, the Federal Government of Nigeria [109] reported the quick growth (i.e., incessant development of artificial surfaces) in metropolitan Lagos and its attainment of Megacity status with an extent of over 153,540 hectares of land consisting of adjourning Ado-Odo/Ota, Ifo, Obafemi-Owode, and Sagamu LGAs of Ogun State. Moreover, research by Braimoh and Onishi [55] found that rising demand for urban land in Lagos is being met by converting rural land at the fringe of existing artificial surfaces. 


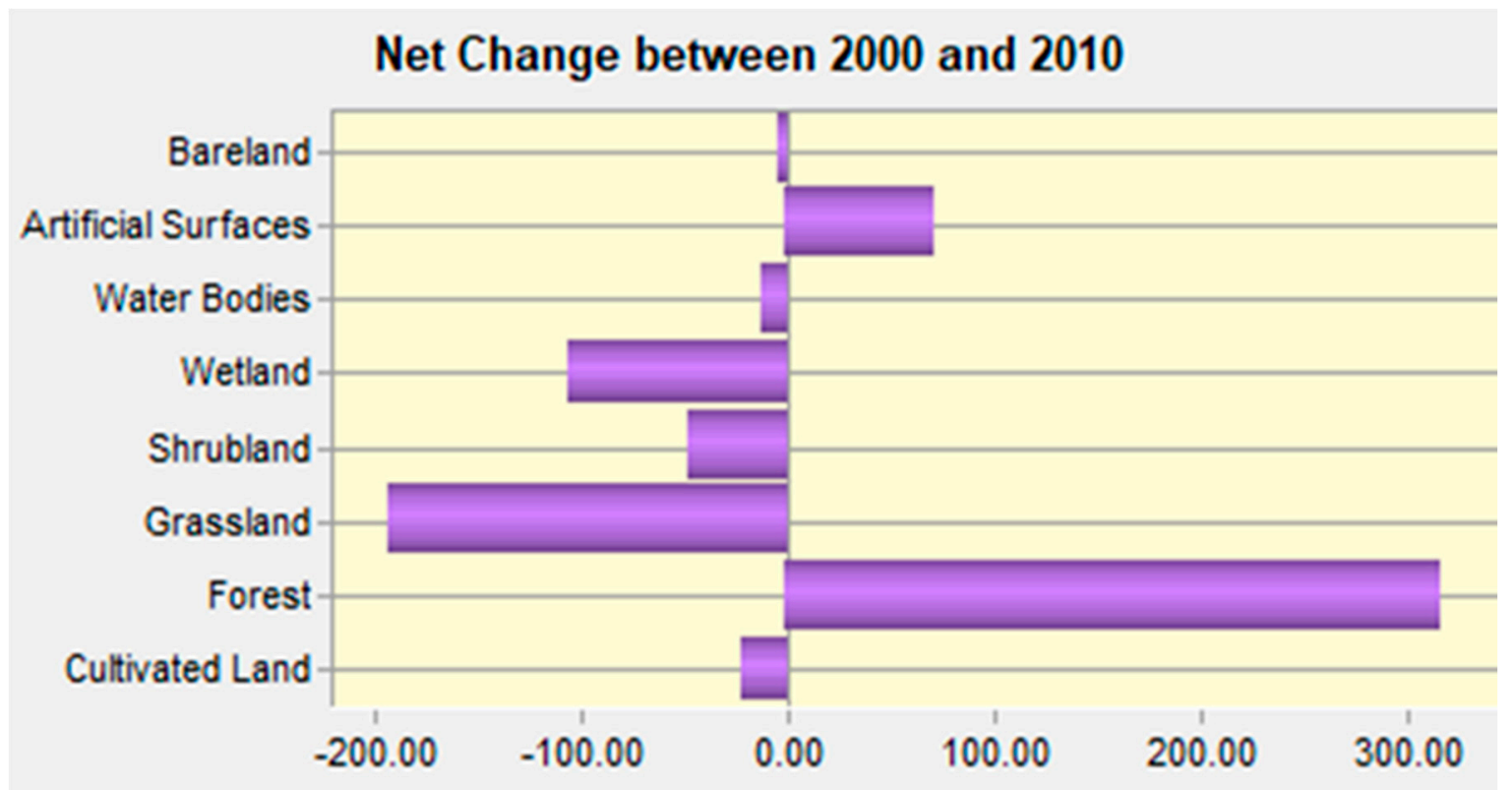

Figure 7. Net change in LULC $\left(\mathrm{km}^{2}\right)$ between 2000 and 2010.

Figure 8 shows the combined LULC change map during 2000 to 2010.

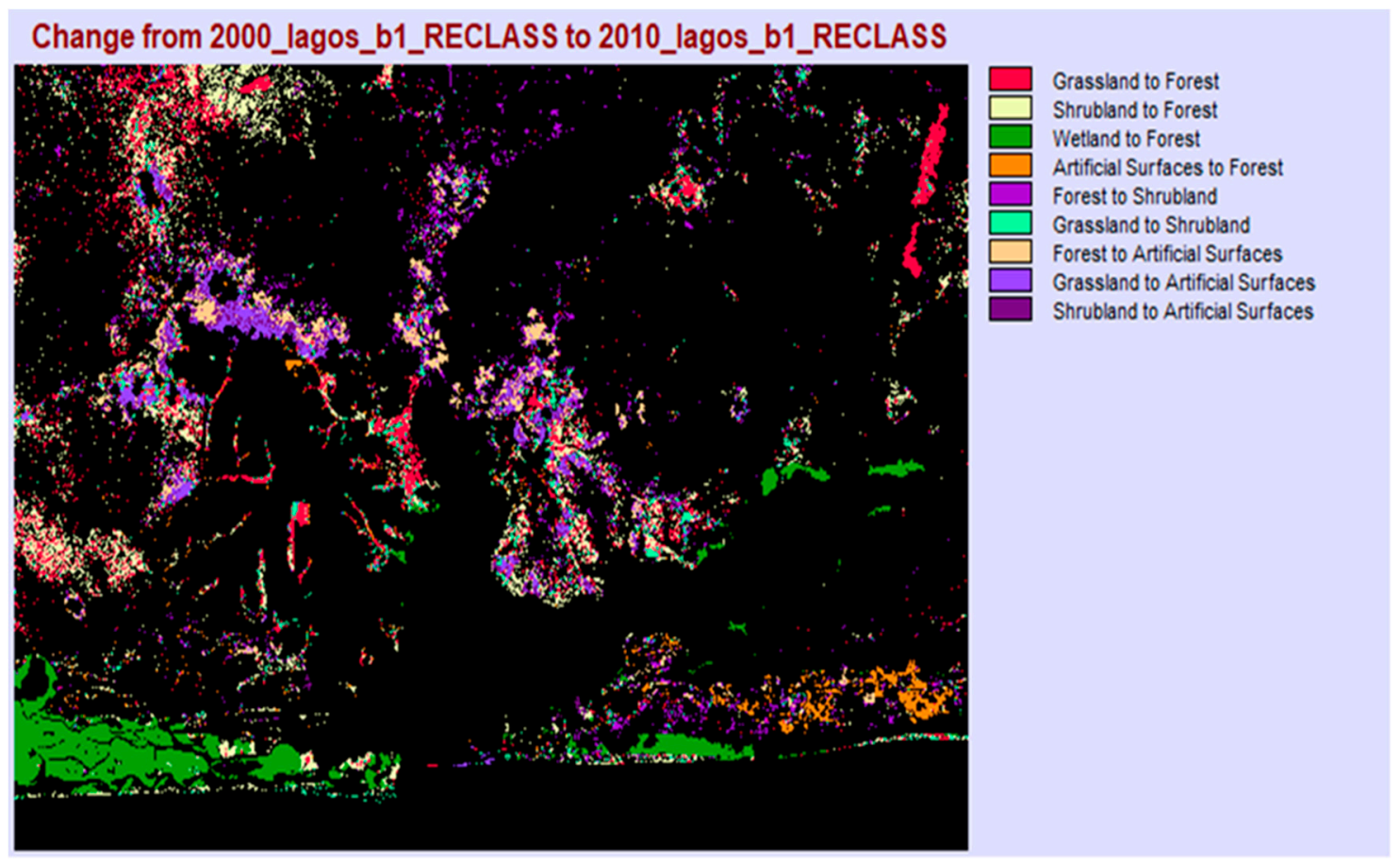

Figure 8. Combined LULC changes between 2000-2010.

\subsection{Driving Factors of LULC Change}

LULC changes are naturally associated with elevation and slope [110]. This study revealed that most of the LULC change in Lagos metropolitan region occurred with elevation of between 0-83.75m (small effects of elevation) (Figure 9a). Therefore, the extent of elevation in Lagos is low. Additionally, zones with higher elevation are more suitable for settlement, whereas zones with low elevations are not easily accessible for settlement and agriculture [111]. Findings show that slope occurred between 0-10 degrees in most parts of 
the Lagos metropolitan region (Figure 9b), implying that slope correlated with less impact on the growth of the zone. This might be due to the flat terrain in Lagos having slope constraints that are not significant [108]. Flat topography, in contrast to hilly zones, could be cost-effective for environmental and city planners in the built environment in Lagos State. Additionally, the influence of elevation and slope may decline in the future because of technological developments and consequent reductions in the cost of construction in hilly sites [89,112]. Cognizance of the impacts of elevation and slope on LULC is crucial to the efficient planning and implementation of policies that enhance sustainable natural resource management [113].

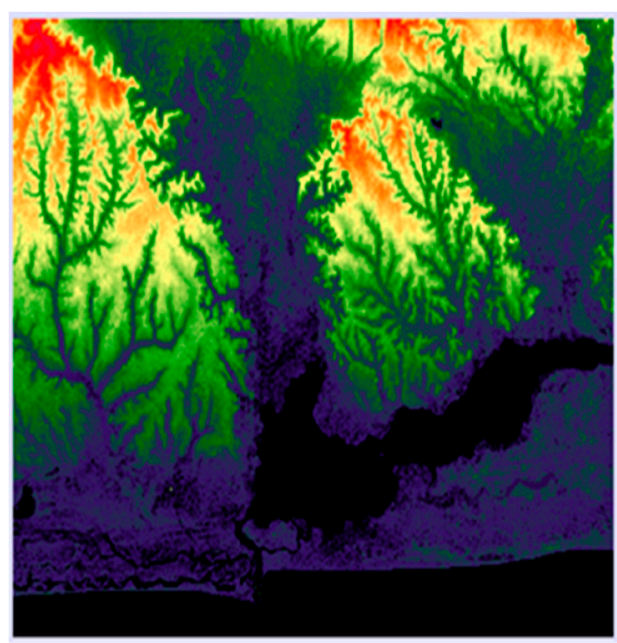

(a) Elevation

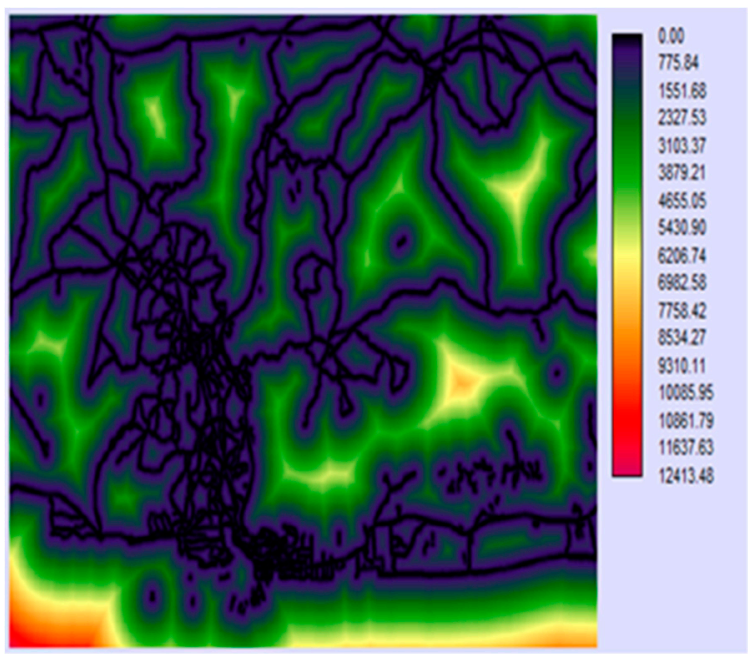

(c) Distance from roads

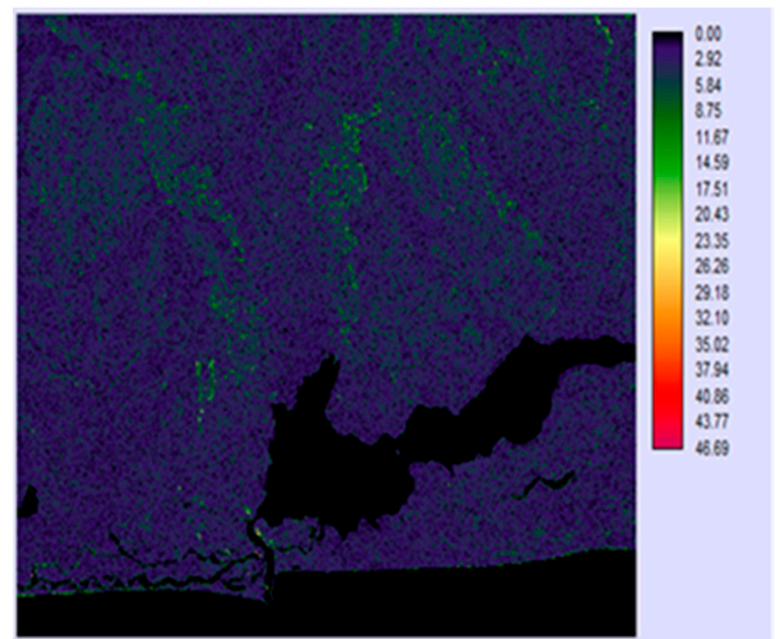

(b) Slope

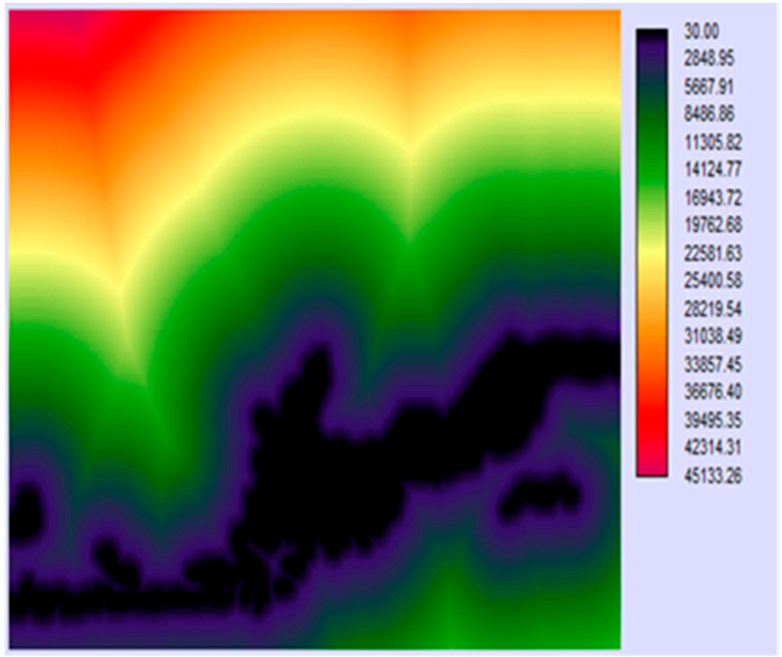

(d) Distance from water bodies

Figure 9. (a-d) Analysis of driving factors of LULC change.

Regarding accessibility factors, progress has been made in constructing new roads and maintaining the existing ones (Figure 9c). Road construction strongly induced deforestation in Nigeria, and proximity to roads encourages frontier residential development [55]. By 2001, Lagos State had constructed $5514 \mathrm{~km}$ of tarred roads. About one third of these roads were made of concrete deck, $43.0 \%$ were covered with asphaltic concrete, and $23.2 \%$ contained bitumen [114]. The study also displayed that distance from water is an important spatial determinant for urban growth (Figure 9d). Accordingly, Braimoh and Onishi [55] found that the likelihood of residential development in Lagos decreases with an increase in distance from waterbodies. 


\subsection{Markov Chain Analysis}

Table 6 presents the transition probability matrix (computed using Markov chain) between 2000 and 2010, including a prediction for 2030. The transition probability matrix consists of rows and columns, as well as diagonal values which depict the probability that each LULC class remains constant from time zero to one [115]. The results indicate that the probability of future change for cultivated land to artificial surfaces was $8.17 \%$, and for forest to artificial surfaces, was $3.72 \%$. Additionally, the probabilities of future changes for grassland, shrubland, wetland, water bodies, and bare land to artificial surfaces were $22.41 \%, 15.90 \%, 2.27 \%, 0.64 \%$, and $9.35 \%$, respectively. Moreover, the probabilities of future changes for water bodies to artificial surfaces, cultivated land, forest, grassland, shrubland, and wetland were $0.64 \%, 0.15 \%, 4.98 \%, 0.92 \%, 0.62 \%$, and $3.94 \%$, correspondingly. Therefore, the probability of future change of other LULC classes to artificial surfaces were superior in grassland and shrubland, implying that there are likelihoods of larger future change of vegetation to artificial surfaces in the Lagos metropolitan region. Waterbodies also have the least likelihood of future change to artificial surfaces in the study area.

Table 6. Markov transition probability matrix and LULC change for 2030.

\begin{tabular}{ccccccccc}
\hline $\begin{array}{c}\text { LULC } \\
\text { Class }\end{array}$ & $\begin{array}{c}\text { Cultivated } \\
\text { Land }\end{array}$ & Forest & Grassland & Shrubland & Wetland & $\begin{array}{c}\text { Water } \\
\text { Bodies }\end{array}$ & $\begin{array}{c}\text { Artificial } \\
\text { Surfaces }\end{array}$ & Bare Land \\
\hline $\begin{array}{c}\text { Cultivated } \\
\text { land }\end{array}$ & 0.0002 & 0.8385 & 0.0092 & 0.0499 & 0.0071 & 0.0134 & 0.0817 & 0.0000 \\
Forest & 0.0000 & 0.9203 & 0.0035 & 0.0311 & 0.0062 & 0.0017 & 0.0372 & 0.0000 \\
$\begin{array}{c}\text { Grassland } \\
\text { Shrubland }\end{array}$ & 0.0001 & 0.6917 & 0.0139 & 0.0618 & 0.0046 & 0.0037 & 0.2241 & 0.0000 \\
Wetland & 0.0001 & 0.7548 & 0.0122 & 0.0569 & 0.0087 & 0.0083 & 0.1590 & 0.0000 \\
$\quad \begin{array}{c}\text { Water } \\
\text { bodies }\end{array}$ & 0.0015 & 0.0498 & 0.0092 & 0.0062 & 0.0394 & 0.8875 & 0.0064 & 0.0000 \\
Artificial & 0.0002 & 0.0964 & 0.0063 & 0.0292 & 0.0015 & 0.0028 & 0.8636 & 0.0000 \\
surfaces & & 0.7165 & 0.0106 & 0.0349 & 0.1734 & 0.0417 & 0.0227 \\
Bare land & 0.0001 & 0.7873 & 0.0159 & 0.0675 & 0.0280 & 0.0077 & 0.0935 & 0.0000 \\
\hline
\end{tabular}

\subsection{LULC Prediction}

Table 7 displays the matching area statistics and the predicted extent of the different LULC classes for year 2030. Forest demonstrated the largest predicted amount of $68.20 \%$; this increase may be related to urban renewal through the constant planting of trees by Lagos State Parks and Garden Agency (LASPARK). In contrast, some studies in land use and urban sprawl in Nigeria reported a predicted reduction in forest cover $[77,116,117]$.

Table 7. Area statistics of predicted LULC in 2030.

\begin{tabular}{ccc}
\hline \multirow{2}{*}{ LULC Classes } & \multicolumn{2}{c}{ Predicted $\mathbf{2 0 3 0}$} \\
\cline { 2 - 3 } & Area $\mathbf{( k m}^{\mathbf{2}} \mathbf{)}$ & Area $\mathbf{( \% )}$ \\
\hline Cultivated Land & 1.33 & 0.03 \\
Forest & 3084.93 & 68.20 \\
Grassland & 0.92 & 0.02 \\
Shrubland & 110.42 & 2.44 \\
Wetland & 34.54 & 0.76 \\
Water Bodies & 423.06 & 9.35 \\
Artificial Surfaces & 867.90 & 19.19 \\
Total area & 4523.10 & 100.00 \\
\hline
\end{tabular}

Accordingly, decrease in forest size and quality constitute environmental threats to the well-being of communities residing in the vicinity of forests [118]. Artificial surfaces were also predicted to have large spatial extent of $19.19 \%$ with continuous decrease in 
the quantities of water bodies (9.3\%), shrubland (2.44\%), and wetland $(0.76 \%)$, including steady declines in the amounts of the cultivated land and grassland.

Additionally, Figure 10 shows the LULC change map predicted for year 2030.

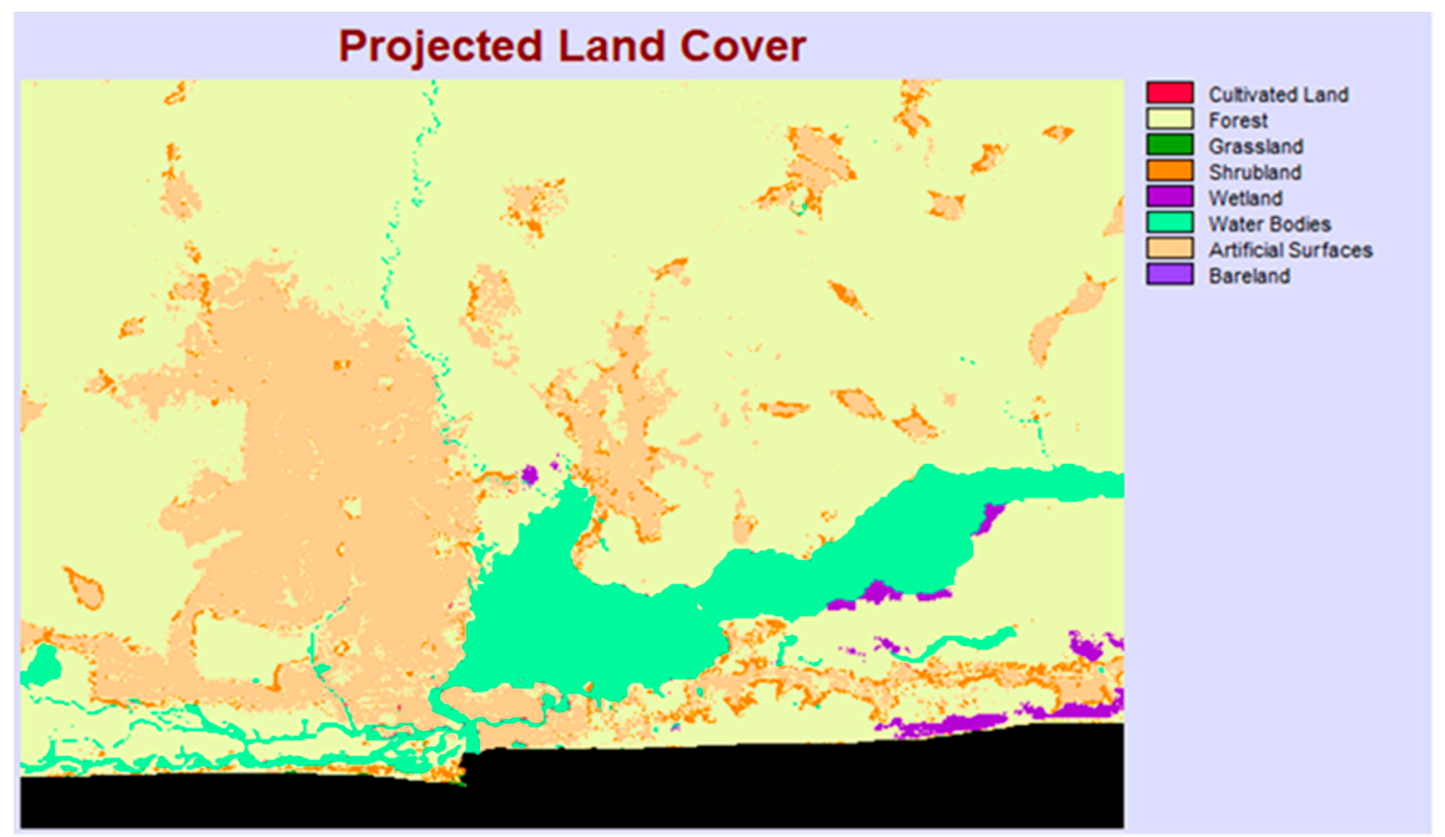

Figure 10. Predicted LULC map for year 2030.

\section{Conclusions}

This study was carried out to ascertain the urban sprawl and growth prediction for Lagos, Nigeria using GlobeLand30 data combined with GIS and Cellular Automata model. The GlobeLand30 dataset were imported into Esri ArcGIS software to create the LULC classified maps for 2000 and 2010. An integrated CA Markov built in LCM module within TerrSet software was used to predict future patterns of LULC change. Additionally, this study showed an increment in the quantity of artificial surfaces between 2000 and 2010 . LULC change analysis presented substantial gains and net changes in the amounts of forest and artificial surfaces, substantial losses of grassland and shrubland, and reduction of wetland, while there was no appreciable impact of change for bare land in contrast with other land cover types. Additionally, the main contributors to the rise in the quantity of artificial surfaces were the big losses from grassland, forest, and shrubland, while cultivated land and wetland presented slight losses.

A transition probability matrix was generated, which illustrates the transition from 2000 to 2010, including a prediction of LULC for 2030. The results show that there is a larger probability of future change of vegetation (i.e., grassland and shrubland) to artificial surfaces, while waterbodies have the least likelihood of future change to artificial surfaces in the study area. Moreover, the prediction analysis for future LULC showed that artificial surfaces will attain $867.90 \mathrm{~km}^{2}$ by 2030 . An increase of $71.74 \mathrm{~km}^{2}$ in artificial surfaces, and decreases of $40.60 \mathrm{~km}^{2}$ in grassland, $74.63 \mathrm{~km}^{2}$ in shrubland, and $87.27 \mathrm{~km}^{2}$ of wetland were estimated between 2010 and 2030, respectively.

Urban sprawl in Lagos has extended beyond its border to neighboring Ogun State since 2000 [108]. It is evident from this current research (see the classified LULC maps, Figure $4 a, b)$ that rapid urban growth has expanded to some parts of Ogun State. Wang and Maduako [108] reported that about 50\% of new artificial surfaces in Lagos were situated in the territory of Ogun State between 2000-2015. Additionally, in developing countries such as Nigeria, policy makers encounter extraordinary problems about urban planning and LULC management because of the existing high dynamic growth [119]. In order 
to proffer solutions to the problems of the growth of Lagos metropolitan region (and prospective influx of people from Lagos to Ogun State because of rapid population growth), collaborations between the Lagos and Ogun State governments, and other stakeholders including regional planning framework, are required. Thus, the policy makers, urban planners, and stakeholders should consider suitable adaptation options to alleviate the negative impacts of urban expansion, based on past and present land cover changes [120]. Moreover, there have been suggestions by various stakeholders regarding how to promote the economic potentials of Ogun State border towns and integrate these towns to an urban status for socio-economic sustainability at a regional level.

Furthermore, this study displayed the effectiveness of GlobeLand30 dataset and GIS integration with CA Markov as tools for LULC change analysis and future predictions. The availability of GlobeLand30 datasets for this study in Lagos helped to solve the problems associated with generating national land cover maps (for various applications) in developing countries [107] like Nigeria. Additionally, the GlobeLand30 dataset will achieve improved results if it covers beyond 2000 to 2010 (the current 10-year interval) to enable for comparisons between many years or different times. Finally, the combination of GIS with CA is valuable to policymakers in making decisions about land use trends, 3urban sprawl, and environmental management in Nigeria.

Author Contributions: The authors made significant contributions during the study. O.O.O. developed the methodology, collected data, analyzed data, and wrote the manuscript. E.V. reviewed and proofread the manuscript for final submission. All authors have read and agreed to the published version of the manuscript.

Funding: This research received no external funding.

Institutional Review Board Statement: "Not applicable" for studies not involving humans or animals.

Informed Consent Statement: “Not applicable” for studies not involving humans.

Data Availability Statement: The data for this study are as presented in this article.

Acknowledgments: The lead author would like to express gratitude to Eric Vaz for his supervision and participation in the various stages of the study. The authors thank the reviewers for their useful remarks.

Conflicts of Interest: The authors declare no conflict of interest.

\section{References}

1. United Nations Population Fund (UNFPA). 2013. Available online: http://www.unfpa.org/pds/urbanization.htm (accessed on 28 April 2020).

2. Shi, Z.-H.; Chen, L.-D.; Hao, J.-P.; Wang, T.-W.; Cai, C.-F. The effects of land use change on environmental quality of the red soil hilly region, China: A case study in Xianning county. Environ. Monit. Assess. 2009, 150, 295-306. [CrossRef]

3. Keshtkar, H.; Voigt, W. A spatiotemporal analysis of landscape change using an integrated Markov chain and cellular automata models. Model. Earth Syst. Environ. 2016, 2, 10. [CrossRef]

4. United Nations. World Urbanization Prospects, the 2009 Version; United Nations: New York, NY, USA, 2010.

5. Trivedi, J.K.; Sareen, H.; Dhyani, M. Rapid urbanization-Its impact on mental health: A South Asian perspective. Indian J. Psychiatry 2008, 50, 161-165. [CrossRef]

6. O'Neill, B.C.; Ren, X.; Jiang, L.; Dalton, M. The effect of urbanization on energy use in India and China in the iPETS model. Energy Econ. 2012, 34, S339-S345. [CrossRef]

7. Gill, J. The Effect of Urban Sprawl on Sydney's Peri-Urban Agricultural Region. Society, Environmental Policy, and Sustainability. Master's Thesis, University of New South Wales, Sydney, NSW, Australia, 2008.

8. Rubiera-Morollón, F.; Garrido-Yserte, R. Recent literature about urban sprawl: A renewed relevance of the phenomenon from the perspective of environmental sustainability. Sustainability 2020, 12, 6551. [CrossRef]

9. Richardson, H.W.; Chang-Hee, C.B. Urban sprawl in Western Europe and the United States; Ashgate: London, UK, 2004.

10. Razin, E. Policies to control urban sprawl: Planning regulations or changes in the "rules of the game". J. Urban Stud. 1998, 35, 321-340. [CrossRef]

11. Tong, X.; Zhang, X.; Liu, M. Detection of urban sprawl using a genetic algorithm-evolved artificial neural network classification in remote sensing: A case study in Jiading and Putuo districts of Shanghai, China. Int. J. Remote Sens. 2010, 31, 1485-1504. [CrossRef] 
12. Burchell, R.W.; Lowenstein, G.; Dolphin, W.R.; Galley, C.C.; Downs, A.; Seskin, S. The Benefits of Sprawl. Chapter 12 A in the Costs of Sprawl Revisited; Transportation Research Board and National Research Council: Washington, DC, USA, 2000.

13. Deng, J.S.; Wang, K.; Hong, Y.; Qi, J.G. Spatiotemporal dynamics and evolution of land use change and landscape pattern in response to rapid urbanization. Landsc. Urban Plan. 2009, 92, 187-198. [CrossRef]

14. Weng, Y.C. Spatiotemporal changes of landscape pattern in response to urbanization. Landsc. Urban Plan. 2007, 81, 341-354. [CrossRef]

15. UN-Habitat. State of the World's Cities 2010/2011; Earthscan: London, UK, 2010.

16. UN-Habitat. Urbanization and Development Emerging Futures World Cities Report; UN-Habitat: Nairobi, Kenya, 2016.

17. Obiefuna, J.N.; Nwilo, P.C.; Atagbaza, A.O.; Okolie, C.J. Land cover dynamics associated with the spatial changes in the wetlands of Lagos/Lekki lagoon system of Lagos, Nigeria. J. Coast. Res. 2013, 29, 671-679.

18. Shrestha, M.K.; York, A.M.; Boone, C.G.; Zhang, S. Land fragmentation due to rapid urbanization in the Phoenix metropolitan area: Analyzing the spatiotemporal patterns and drivers. Appl. Geogr. 2011, 32, 522-531. [CrossRef]

19. Solon, J. Spatial context of urbanization: Landscape pattern and changes between 1950 and 1990 in the Warsaw metropolitan area, Poland. Landsc. Urban Plan. 2009, 93, 250-261. [CrossRef]

20. United Nations, Department of Economic and Social Affairs, Population Division. World Urbanization Prospects. 2018. Available online: https:// www.un.org/development/desa/publications/2018-revision-of-world-urbanization-prospects.html (accessed on 16 July 2020).

21. United Nations Population Division. World Population Prospects: 2019 Revision. Population of Nigeria. Available online: https:/ / data.worldbank.org/indicator/SP.POP.TOTL?locations=NG (accessed on 20 August 2020).

22. United Nations. World Urbanization Prospects: The 2014 Revision, Highlights (ST/ESA/SER.A/352); United Nations, Department of Economic and Social Affairs, Population Division: New York, NY, USA, 2014.

23. Mabogunje, A.L. Urban Development in Nigeria; University of London Press: London, UK, 1968.

24. Aniah, E.J. The role of secondary cities in regional economic development in Nigeria. J. Environ. Sci. $2001,4,112-119$.

25. Federal Government of Nigeria (FGN). Nigeria: Country Profile Implementation of Agenda 21: Review of Progress Made Since The United Nations Conference on Environment and Development, 1992 Information Provided by The Government of Nigeria to The United Nations Commission on Sustainable Development Fifth Session. In Proceedings of the United Nations Conference on Environment and Development, New York, NY, USA, 7-25 April 1997; FGN: Lagos, Nigeria, 1997.

26. United States Library of Congress. Nigeria Urbanization Source; U.S. Library of Congress: Washington, DC, USA, 2013.

27. United Nations. World Urbanization Prospects. 2017. Lagos Population Growth. Available online: http://worldpopulationreview. com/world-cities/lagos-population/ (accessed on 14 July 2020).

28. Vaz, E. Managing urban coastal areas through landscape metrics: An assessment of Mumbai's mangrove system. Ocean Coast. Manag. 2014, 98, 27-37. [CrossRef]

29. Banzhaf, E.; Kabisch, S.; Knapp, S.; Rink, D.; Wolff, M.; Kindler, A. Integrated research on land-use changes in the face of urban transformations-An analytic framework for further studies. Land Use Policy 2017, 60, 403-407. [CrossRef]

30. Vaz, E.; Arsanjani, J.J. Predicting urban growth of the Greater Toronto area-Coupling a Markov cellular automata with document meta-analysis. J. Environ. Inform. 2015, 25, 71-80. [CrossRef]

31. Hachmann, S.; Arsanjani, J.J.; Vaz, E. Spatial data for slum upgrading: Volunteered Geographic Information and the role of citizen science. Habitat Int. 2018, 72, 18-26. [CrossRef]

32. Hathout, S. The use of GIS for monitoring and predicting urban growth in East and West St Paul, Winnipeg, Manitoba, Canada. J. Environ. Manag. 2002, 66, 229-238. [CrossRef]

33. Herold, M.; Goldstein, N.C.; Clarke, K.C. The spatiotemporal form of urban growth: Measurement, analysis, and modeling. Remote Sens. Environ. 2003, 86, 286-302. [CrossRef]

34. Lambin, E.F.; Geist, H.; Lepers, E. Dynamics of land use and land cover changes in tropical regions. Annu. Rev. Environ. Resour. 2003, 28, 205-241. [CrossRef]

35. Wu, Q.; Li, H.; Wang, R.; Paulussen, J.; He, Y.; Wang, M.; Wang, B.; Wang, Z. Monitoring and predicting land use change in Beijing using remote sensing and GIS. Landsc. Urban Plan. 2006, 78, 322-333. [CrossRef]

36. Arsanjani, J.J.; Helbich, M.; Kainz, W.; Boloorani, A.D. Integration of logistic regression, Markov chain and cellular automata models to simulate urban expansion. Int. J. Appl. Earth Obs. Geoinf. 2013, 21, 265-275. [CrossRef]

37. Liu, X.; Ma, L.; Li, X.; Ai, B.; Li, S.; He, Z. Simulating urban growth by integrating landscape expansion index LEI and cellular automata. Int. J. Geogr. Inf. Sci. 2014, 28, 148-163. [CrossRef]

38. Wu, F.; Webster, C.J. Simulation of land development through the integration of cellular automata and multicriteria evaluation. Environ. Plan. B Plan. Des. 1998, 25, 103-126. [CrossRef]

39. Store, R.; Kangas, J. Integrating spatial multi-criteria evaluation and expert knowledge for GIS-based habitat suitability modeling. Landsc. Urban Plan. 2001, 55, 79-93. [CrossRef]

40. Collins, M.G.; Steiner, F.R.; Rushman, M.J. Land-use suitability analysis in the United States: Historical development and promising technological achievements. Environ. Manag. 2001, 28, 611-621. [CrossRef]

41. Malczewski, J. GIS-based land-use suitability analysis: A critical overview. Prog. Plan. 2004, 62, 3-65. [CrossRef]

42. Vaz, E.N.; Nijkamp, P.; Painho, M.; Caetano, M. A multi-scenario forecast of urban change: A study on urban growth in the Algarve. Landsc. Urban Plan. 2012, 104, 201-211. [CrossRef] 
43. Al-Sharif, A.A.A.; Pradhan, B. A novel approach for predicting the spatial patterns of urban expansion by combining the chi-squared automatic integration detection decision tree, Markov chain and cellular automata models in GIS. Geocarto Int. 2015, 30, 858-881. [CrossRef]

44. He, C.Y.; Okada, N.; Zhang, Q.F.; Shi, P.J.; Li, J.G. Modelling dynamic urban expansion processes incorporating a potential model with cellular automata. Landsc. Urban Plan. 2008, 86, 79-91. [CrossRef]

45. White, R.; Engelen, G. Cellular automata and fractal urban form: A cellular modeling approach to the evolution of urban land-use patterns. Environ. Plan. A 1993, 25, 1175-1199. [CrossRef]

46. Wu, F. Calibration of stochastic cellular automata: The application to rural-urban land conversions. Int. J. Geogr. Inf. Sci. 2002, 16, 795-818. [CrossRef]

47. Liu, Y.; Feng, Y. Simulating the impact of economic and environmental strategies on future urban growth scenarios in Ningbo, China. Sustainability 2016, 8, 1045. [CrossRef]

48. Hyandye, C.; Martz, L.W. A Markovian and cellular automata land-use change predictive model of the Usangu Catchment. Int. J. Remote Sens. 2017, 38, 64-81. [CrossRef]

49. Mondal, M.S.; Sharma, N.; Garg, P.K.; Kappas, M. Statistical independence test and validation of CA Markov land use land cover (LULC) prediction results. Egypt. J. Remote Sens. Space Sci. 2015, 19, 259-272. [CrossRef]

50. Zhilong, Z.; Xue, W.; Yili, Z.; Jungang, G. Assessment of changes in the value of ecosystem services in the Koshi River Basin, central high Himalayas based on land cover changes and the CA-Markov model. J. Resour. Ecol. 2017, 8, 67-76. [CrossRef]

51. Paegelow, M.; Camacho Olmedo, M.T.; Mas, J.F.; Houet, T. Benchmarking of LULC modelling tools by various validation techniques and error analysis. Cybergeo Eur. J. Geogr. 2014. [CrossRef]

52. Veldkamp, A.; Lambin, E.F. Predicting land-use change. Agric. Ecosyst. Environ. 2001, 85, 1-6. [CrossRef]

53. Awoniran, D.R.; Adewole, M.B.; Adegboyega, S.S.; Anifowose, Y. Assessment of environmental responses to land use/land cover dynamics in the lower Ogun River Basin, Southwestern Nigeria. Int. J. Sustain. Land Use Urban Plan. 2014, 1, 16-31. [CrossRef]

54. Babalola, O.S.; Akinsanola, A.A. Change detection in land surface temperature and land use land cover over Lagos metropolis, Nigeria. J. Remote Sens. GIS 2016, 5, 3.

55. Braimoh, A.K.; Onishi, T. Spatial determinants of urban land use change in Lagos, Nigeria. Land Use Policy 2007, $24,502-515$. [CrossRef]

56. Dekolo, S.O.; Nwokoro, I.I.C.; Oduwaye, O.A. Peri-Urban Land Use Change in the Lagos Megacity; International Post Graduate Research: Salford, UK, 2013.

57. Jimoh, R.A.; Afonja, Y.O.; Atagbaza, A.O.; Nilanchal, P. Spatial modeling and mapping of the land use and land cover of Lagos Mainland Local Government, Lagos State, Nigeria using geospatial data. J. Stud. Manag. Plan. 2015, 1, $182-191$.

58. Ukor, C.D.; Ogbole, J.; Alaga, A.T. Analysis of land use land cover change in Ikeja, Lagos State Nigeria using remote sensing and GIS techniques. Int. J. Sci. Technol. 2016, 5, 462-472.

59. Obiefuna, J.N.; Idris, S.; Uduma-Olugu, N. An assessment of the changes in the landscape of Ogudu-Oworonshoki development prone area of Lagos Metropolis, Nigeria. J. Sustain. Dev. 2011, 4, 82-93. [CrossRef]

60. Barredo, J.I.; Demicheli, L.; Lavalle, C.; Kasanko, M.; Mccormick, N. Modelling future urban scenarios in developing countries: An application case study in Lagos, Nigeria. Environ. Plan. B Plan. Des. 2004, 31, 65-84. [CrossRef]

61. Global Literacy Project. n.d. Global Citizens Classroom. Available online: http:/ /www.glpinc.org/Classroom\%20Activities/ Nigeria\%20Articles/Nigeriahistory\%20since\%201960.htm (accessed on 10 March 2020).

62. Regional Geographic Data of Nigeria. Lagos. 2010. Available online: http://nigeria.opendataforafrica.org/apps/atlas/Lagos (accessed on 6 March 2020).

63. Balogun, Y.O.; Odumosu, O.J.; Ojo, O.A. (Eds.) Lagos in Maps; Punmark Publications: Lagos, Nigeria, 1999.

64. Agbola, T.; Agunbiade, E.M. Urbanization, slum development and security of tenure: The challenges of meeting Millennium Development Goal 7. In Urban Population-Environment Dynamics in the Developing World: Case Studies and Lessons Learned; de Sherbiniin, A., Rahman, A., Barbieri, A., Fotso, J.C., Zhu, Y., Eds.; Committee for International Cooperation in National Research in Demography (CICRED): Paris, France, 2009.

65. Department of Economic and Social Affairs/Population Division, United Nations. World Urbanization Prospects: The 2011 Revision; UN: New York, NY, USA, 2011.

66. Filani, M.O. The Changing Face of Lagos: From Vision to Reform and Transformation. Cities Alliance, Brussels. 2012. Available online: http:/ / www.citiesalliance.org/sites/citiesalliance.org/files/Lagos-reformreport-lowres.pdf (accessed on 10 March 2020).

67. Williams, L. Bradt Guide: Nigeria; Connecticut: The Globe Prequot Press Inc.: Guildford, CT, USA, 2008; Available online: http:/ / books.google.com/books?id=fwuQ71ZbaOcC\&pg=PA110\#v=onepage\&q\&f=false (accessed on 10 September 2020).

68. Ogunbiyi, T. Giving Lagos a Special Status. 2011. Vanguard Newspaper. Available online: http://www.vanguardngr.com/2011 /08/giving-lagos-a-special-status/ (accessed on 8 March 2020).

69. Okeke, F. Nigeria: FCC Condemns Nepotism. Daily Trust. 2012. Available online: http://allafrica.com/stories/201211160413 .html (accessed on 25 March 2020).

70. Nwafor, J.C. Physical environment, decision-making and land use development in metropolitan Lagos. GeoJournal 1986, 12, 433-442. [CrossRef]

71. Akinsanmi, G. Lagos Emerges Africa's Most Innovative City. This Day Live. 2012. Available online: http://www.thisdaylive. com/articles/lagos-emerges-africa-s-mostinnovative-city/128001/ (accessed on 25 March 2020). 
72. Thontteh, E.O.; Omirin, M.M. Land registration within the framework of land administration reform in Lagos State. Pac. Rim Prop. Res. J. 2015, 21, 161-177. [CrossRef]

73. The Lands Bureau, Lagos State Land Bureau Handbook; The Lands Bureau, Governor's Office Publication: Lagos, Nigeria, 2010.

74. Arsanjani, J.J.; Tayyebi, A.; Vaz, E. GlobeLand30 as an alternative fine-scale global land cover map: Challenges, possibilities, and implications for developing countries. Habitat Int. 2016, 55, 25-31. [CrossRef]

75. Arsanjani, J.J. Characterizing, monitoring, and simulating land cover dynamics using GlobeLand30: A case study from 2000 to 2030. J. Environ. Manag. 2018, 214, 66-75. [CrossRef]

76. Chen, J.; Liao, A.P.; Cao, X.; Chen, L.J.; Chen, X.H.; He, C.Y.; Han, G.; Peng, S.; Lu, M.; Zhang, W.W.; et al. Global land cover mapping at 30 m resolution: A POK-based operational approach. ISPRS J. Photogramm. Remote Sens. 2015, 103, 7-27. [CrossRef]

77. Arowolo, A.O.; Deng, X. Land use/land cover change and statistical modelling of cultivated land change drivers in Nigeria. Reg. Environ. Chang. 2018, 18, 247-259. [CrossRef]

78. Zhang, L.; Pfoser, D. Using OpenStreetMap point-of-interest data to model urban change-A feasibility study. PLoS ONE 2019, 14, e0212606. [CrossRef]

79. Fonte, C.C.; Patriarca, J.A.; Minghini, M.; Antoniou, V.; See, L.; Brovelli, M.A. Using OpenStreetMap to create land use and land cover maps: Development of an application. In Volunteered Geographic Information and the Future of Geospatial Data; Campelo, C.E.C., Bertolotto, M., Corcoran, P., Eds.; IGI Global: Hershey, PA, USA, 2017; pp. 113-137.

80. Eastman, J.R. IDRISI Andes Guide to GIS and Image Processing; Clark University: Worcester, MA, USA, 2006.

81. Eastman, J.R. IDRISI Selva Tutorial; Clark University: Worcester, MA, USA, 2012.

82. Eastman, J.R. TerrSet Tutorial; Clark University: Worcester, MA, USA, 2020.

83. Wahyudi, A.; Liu, Y. Cellular automata for urban growth modeling: A review on factors defining transition rules. Int. Rev. Spat. Plan. Sustain. Dev. 2016, 4, 60-75.

84. Mitsuda, Y.; Ito, S. A review of spatial-explicit factors determining spatial distribution of land use/land-use change. Landsc. Ecol. Eng. 2010, 7, 117-125. [CrossRef]

85. Geneletti, D. Assessing the impact of alternative land-use zoning policies on future ecosystem services. Environ. Impact Assess. Rev. 2013, 40, 25-35. [CrossRef]

86. Eastman, J.R. IDRISI TerrSet Tutorial; Clark University: Worcester, MA, USA, 2015.

87. Müller, K.; Steinmeier, C.; Kuchler, M. Urban growth along motorways in Switzerland. Landsc. Urban. Plan. 2010, 98, 3. [CrossRef]

88. Reilly, M.K.; O'Mara, M.P.; Seto, K.C. From Bangalore to the Bay area: Comparing transportation and activity accessibility as drivers of urban growth. Landsc. Urban. Plan. 2009, 92, 24-33. [CrossRef]

89. Ye, Y.; Zhang, H.; Liu, K.; Wu, Q. Research on the influence of site factors on the expansion of construction land in the Pearl River Delta, China: By using GIS and remote sensing. Int. J. Appl. Earth Obs. Geoinf. 2013, 21, 366-373. [CrossRef]

90. Luo, J.; Wei, Y. Modeling spatial variations of urban growth patterns in Chinese cities: The case of Nanjing. Landsc. Urban. Plan. 2009, 91, 51-64. [CrossRef]

91. Poelmans, L.; Rompaey, A.V. Detecting and modelling spatial patterns of urban sprawl in highly fragmented areas: A case study in the Flanders-Brussels region. Landsc. Urban. Plan. 2009, 93, 10-19. [CrossRef]

92. Engelen, G. Cellular Automata for Modelling Land Use Change as Driven by Socio-Economic, Environmental and Policy Factors; Research Institute for Knowledge System (RIKS): Maastricht, The Netherlands, 2006.

93. Delden, H.V.; Stuczynski, T.; Ciaian, P.; Paracchini, M.L.; Hurkens, J.; Lopatka, A.; Shi, Y.-E.; Prieto, O.G.; Calvo, S.; Van Vliet, J.; et al. Integrated assessment of agricultural policies with dynamic land use change modelling. Ecol. Model. 2010, 221, 2153-2166. [CrossRef]

94. Deng, X.; Huang, J.; Rozelle, S.; Zhang, J.; Li, Z. Impact of urbanization on cultivated land changes in China. Land Use Policy 2015, 45, 1-7. [CrossRef]

95. Rumelhart, D.E.; Hinton, G.E.; Williams, R.J. Learning internal representations by error propagation. In Parallel Distributed Processing: Explorations in the Microstructure of Cognition; Rumelhart, D.E., McClelland, J.L., Eds.; MIT Press: Cambridge, MA, USA, 1986; Volume 1, pp. 318-362.

96. Artificial Intelligence Wiki. n.d. A Beginner's Guide to Multilayer Perceptrons (MLP). Available online: https://skymind.ai/ wiki/multilayer-perceptron (accessed on 26 March 2020).

97. White, R.; Engelen, G. Cellular automata as the basis of integrated dynamic regional modelling. Environ. Plan. B 1997, 24, 235-246. [CrossRef]

98. Yang, X.; Zheng, X.Q.; Chen, R. A land use change model: Integrating landscape pattern indexes and Markov-CA. Ecol. Model. 2014, 283, 1-7. [CrossRef]

99. Parsa, V.A.; Yavari, A.; Nejadi, A. Spatio-temporal analysis of land use/land cover pattern changes in Arasbaran biosphere reserve: Iran. Model. Earth Syst. Environ. 2016, 4, 1-13. [CrossRef]

100. Wang, J.; Stein, A.; Gao, B.; Ge, Y. A review of spatial sampling. Spat. Stat. 2012, 2, 1-14. [CrossRef]

101. Berto, F.; Tagliabue, J. Cellular Automata. The Stanford Encyclopedia of Philosophy Edward. Zalta, N., Ed.; 2017. Available online: https:/ / plato.stanford.edu/archives/fall2017/entries/cellular-automata (accessed on 9 January 2020).

102. Muller, M.R.; Middleton, J. A Markov model of land use change dynamics in the Niagara region, Ontario, Canada. Landsc. Ecol. 1994, 9, 151-157. 
103. Surabuddin Mondal, M.; Sharma, N.; Kappas, M.; Garg, P.K. Modeling of spatio-temporal dynamics of land use and land cover in a part of Brahmaputra river basin using geoinformatic techniques. Geocarto Int. 2013, 28, 632-656. [CrossRef]

104. Adhikari, S.; Southworth, J. Simulating forest cover changes of Bannerghatta National Park based on a CA-Markov model: A remote sensing approach. Remote Sens. 2012, 4, 3215-3243. [CrossRef]

105. Lagos State Government Ministry of the Environment. Tree Planting. Available online: http://moelagos.gov.ng/events/ (accessed on 12 January 2020).

106. Awoniran, D.R.; Adewole, M.B.; Salami, A.T. Wetland conversion and fragmentation pattern with its impacts on soil in the lower Ogun river basin. Ife Res. Publ. Geogr. 2011, 10, 125-133.

107. Arsanjani, J.J. Characterizing and monitoring global landscapes using GlobeLand30 datasets: The first decade of the twenty-first century. Int. J. Digit. Earth 2019, 12, 642-660. [CrossRef]

108. Wang, J.; Maduako, I.N. Spatio-temporal urban growth dynamics of Lagos metropolitan region of Nigeria based on hybrid methods for LULC modeling and prediction. Eur. J. Remote Sens. 2018, 51, 251-265. [CrossRef]

109. Federal Government of Nigeria (FGN). Report of the Presidential Committee on Redevelopment of Lagos Megacity Region; Federal Government of Nigeria: Lagos, Nigeria, 2006.

110. Qasim, H.; Klaus, H.; Termansen, M.; Fleskens, L. Modeling land use change across elevation gradients in district swat, Pakistan. Reg. Environ. Chang. 2013, 13, 567-581. [CrossRef]

111. Birhanu, L.; Hailu, B.T.; Bekele, T.; Demissew, S. Land use/land cover change along elevation and slope gradient in highlands of Ethiopia. Remote Sens. Appl. Soc. Environ. 2019, 16, 100260. [CrossRef]

112. Li, X.; Zhou, W.; Ouyang, Z. Forty years of urban expansion in Beijing: What is the relative importance of physical, socioeconomic, and neighborhood factors? Appl. Geogr. 2013, 38, 1-10. [CrossRef]

113. Birhane, E.; Ashfare, H.; Almaw, A.F.; Hishe, H.; Gebremedhin, A.M.; Hailemariam, G.; Negasi, S. Land use land cover changes along topographic gradients in Society and Hugumburda national forest priority area, Northern Ethiopia. Remote Sens. Appl. Soc. Environ. 2019, 13, 61-68.

114. Atubi, A.O. An evaluation of transport infrastructure in Lagos State, Nigeria. J. Alt. Perspect. Soc. Sci. 2013, 5, 477-494.

115. Halmy, M.W.A.; Gessler, P.E.; Hicke, J.A.; Salem, B.B. Land use/land cover change detection and prediction in the north-western coastal desert of Egypt using Markov-CA. Appl. Geogr. 2015, 63, 101-112. [CrossRef]

116. Tijani, M.N.; Olaleye, A.O.; Olubanjo, O.O. Impact of urbanization on wetland degradation: A case study of Eleyele wetland, Ibadan, South West, Nigeria. In Proceedings of the Environmental Management Conference, Abeokuta, Nigeria, 12-15 September 2011; Federal University of Agriculture: Makurdi, Nigeria, 2011; Volume 2, pp. 308-324.

117. Tope-Ajayi, O.O.; Adedeji, O.H.; Adeofun, C.O.; Awokola, S.O. Land use change assessment, prediction using remote sensing, and GIS aided Markov Chain modelling at Eleyele wetland area, Nigeria. J. Settl. Spat. Plan. 2016, 7, 51-63.

118. Joorabian Shooshtari, S.H.; Hosseini, S.M.; Esmaili-Sari, A.; Gholamalifard, M. Monitoring land cover change, degradation, and restoration of the Hyrcanian forests in northern Iran (1977-2010). Int. J. Environ. Sci. 2012, 3, 1038-1056.

119. Moghadam, H.S.; Helbich, M. Spatiotemporal urbanization processes in the megacity of Mumbai India: A Markov chains-cellular automata urban growth model. Appl. Geogr. 2013, 40, 140-149. [CrossRef]

120. Yin, J.; Yin, Z.; Zhong, H.; Xu, S.; Hu, X.; Wang, J.; Wu, J. Monitoring urban expansion and land use/land cover changes of Shanghai metropolitan area during the transitional economy (1979-2009) in China. Environ. Monit. Assess. 2011, 177, 609-621. [CrossRef] [PubMed] 